PONTIFÍCIA UNIVERSIDADE CATÓLICA DO RIO DE JANEIRO

\title{
A influência dos blogs relacionados a moda, estilo e beleza no comportamento de compra das consumidoras
}

\section{Daniella Samanez Bisso}

Trabalho de Conclusão de Curso

Centro de CIÊNCIAS SOCIAIS - CCS

DePARTAMENTO de AdMINISTRAÇÃo

Graduação em Administração de Empresas 
Daniella Samanez Bisso

\section{A influência dos blogs relacionados a moda, estilo e beleza no comportamento de compra das consumidoras}

\section{Trabalho de Conclusão de Curso}

Trabalho de Conclusão de Curso, apresentado ao programa de graduação em Administração da PUC-Rio como requisito parcial para a obtenção do título de graduação em Administração.

Orientadora: Barbara Levy 


\section{Agradecimentos}

Ao meu pai, meu maior exemplo de vitória. Obrigada pelos conselhos, pelo incentivo e apoio incondicional. 


\section{Resumo}

Samanez Bisso, Daniella. A influência dos blogs relacionados a moda, estilo e beleza no comportamento de compra das consumidoras. Rio de Janeiro, 2016. 68 p. Trabalho de Conclusão de Curso - Departamento de Administração. Pontifícia Universidade Católica do Rio de Janeiro.

O objetivo deste trabalho é compreender a influência que os blogs relacionados a moda, beleza e estilo têm no comportamento de compra das consumidoras de produtos de beleza. Para isso, foi realizada uma pesquisa bibliográfica, incluindo revisão teórica sobre temas pertinentes ao estudo e uma pesquisa de campo. Na etapa da pesquisa de campo, foram realizadas 15 entrevistas exploratórias com consumidoras de produtos de beleza que acessam blogs pelo menos uma vez ao mês. Os resultados obtidos permitiram aferir que existe influência dos blogs relacionados a moda, estilo e beleza sobre o comportamento de compra das consumidoras, principalmente, nas etapas de pesquisa pré-compra, avaliação das alternativas e escolha do produto.

Palavras- chave

Comportamento do consumidor, processo de tomada de decisão, blogs, Internet.

\section{Abstract}

Samanez Bisso, Daniella. The influence of blogs related to fashion, style and beauty on buying behavior. Rio de Janeiro, 2016. 68 p. Final Paper Department of Business Administration. Pontifícia Universidade Católica do Rio de Janeiro.

The goal of this study is to understand the influence that blogs related to fashion, beauty and style have on the buying behavior of beauty products consumers. To do so, a bibliographic research, including a theoretical review of issues relevant to this study, and a field research was conducted. In the stage of field research were carried out 15 exploratory interviews with consumers of beauty products that access blogs at least once a month. The results allowed to infer that there is influence of blogs related to fashion, style and beauty on the buying behavior of consumers, especially in the stages of pre-purchase research, evaluation of alternatives and product choice.

\section{Key-words}

Consumer behaviour, decision making process, blogs, internet. 


\section{Sumário}

1 Introdução

1.1. Introdução ao tema e ao problema do estudo 1

1.2. Objetivo final do estudo 3

1.3. Objetivos intermediários do estudo 3

1.4. Delimitação do estudo 3

1.5. Relevância do estudo 4

2 Referencial teórico 6

2.1. Comportamento do consumidor 6

2.1.1 Fatores de influência no comportamento do consumidor 7

2.1.2 Processo de tomada de decisão 8

2.1.2.1 Busca de informação 8

2.1.2.2. Avaliação de alternativa pré-compra 9

$\begin{array}{ll}\text { 2.1.2.3. Compra } & 10\end{array}$

2.1.3. Grupos de referência 12

2.1.3.1. Líderes de opinião 13

2.1.4. Autoconceito 14

2.1.4.1. Imagem corporal 15

2.2. O mercado de produtos de beleza 15

2.3. Influência da internet no comportamento do consumidor 19

2.3.1. A internet como canal de informação 19

2.3.1.1. Word-of-mouth (WOM) e Electronic word-of mouth (eWOM) 20

$\begin{array}{ll}\text { 2.3.2. Blogs } & 21\end{array}$

2.3.2.1. Conteúdos 25

3 Metodologia 30

3.1. Tipo de pesquisa 30

3.2. Seleção dos sujeitos 30

3.3. Coleta de dados 31

3.4. Tratamento dos dados 32

3.5. Limitação do método 32

4 Apresentação e análise dos resultados 33

4.1. Descrição e análise dos resultados 33 
4.1.1. Caracterização do perfil sócio demográfico das entrevistdas

4.1.2. Hábitos de compra e uso de produtos de beleza 34

4.1.3. Processo de decisão de compra 36

4.1.3.1. Pesquisa de informação na fase pré-compra 37

4.1.3.2. Influência de terceiros no processo de compra 39

4.1.4. Influência dos blogs relacionados a moda, estilo e beleza na decisão de compra $\quad 41$

4.1.4.1. Como descobriram os blogs e a frequência que os acessam 41

4.1.4.2. Aspectos positivos e negativos do conteúdo sob o ponto de vista das entrevistadas

4.1.4.3. Blogs relacionados a moda, estilo e beleza como plataformas de pesquisa de informação na fase pré-compra 45

4.1.4.3.1. Motivações para acessarem os blogs 46

4.1.4.4. Word-of-mouth (WOM) 48

4.1.4.5. O aumento do interesse pelos temas de moda, estilo e beleza 49

4.1.4.6. Influência das autoras de blogs de moda, estilo e beleza 50

5 Conclusões e recomendações para novos estudos 58

5.1. Sugestões e recomendações para novos estudos 61

6 Referências Bibliográficas 63

$\begin{array}{ll}\text { Anexo } 1 & 67\end{array}$ 


\section{Lista de figuras}

Figura 1: Distribuição do número de pessoas no Brasil com acesso, em percentual, segundo a faixa etária no primeiro trimestre de

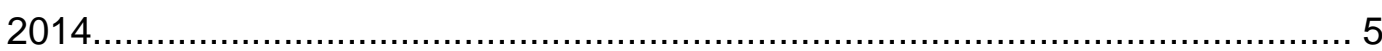

Figura 2: Tempo gasto com mídias sociais ................................................... 5

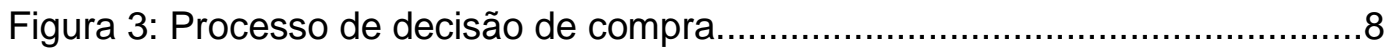

Figura 4: Quatro tipos de comportamento de compra......................................11

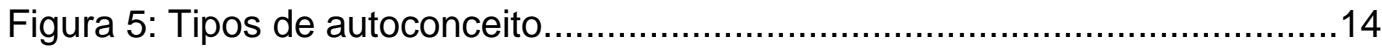

Figura 6: Mercado mundial de higiene pessoal, perfumaria e cosméticos..........16

Figura 7: Papel da internet no consumo de produtos de beleza ...................... 17

Figura 8: Quatro tipos de perfis de mulheres............................................... 18

Figura 9: Onde mulheres procuram de tendências de beleza......................... 23

Figura 10: Onde as mulheres se inspiram ................................................ 23

Figura 11: Conteúdo considerado mais valioso..............................................24

Figura 12: Principais fatores de influência na decisão de compra......................25

Figura 13: Ranking de blogs de moda e beleza mais acessados no Brasil.........26

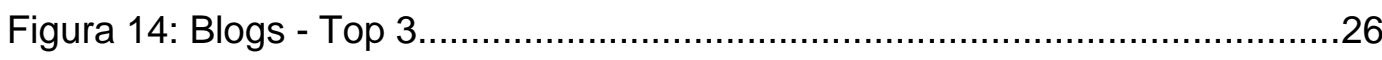

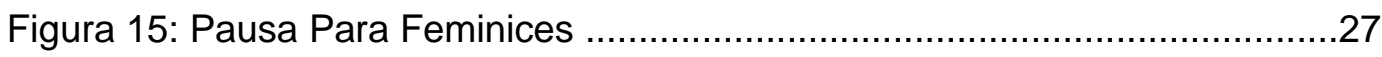

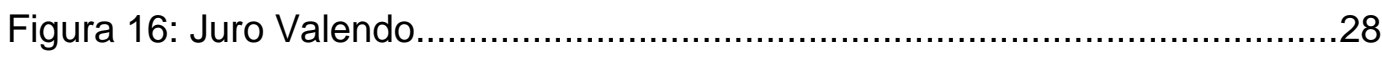

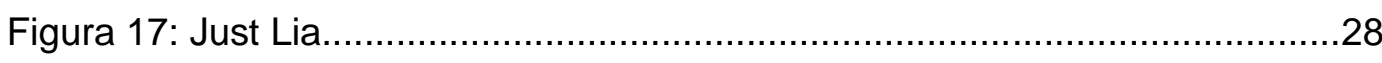

Figura 18: Principais atributos que influenciam na escolha do produto...............36 


\section{Lista de Quadros}

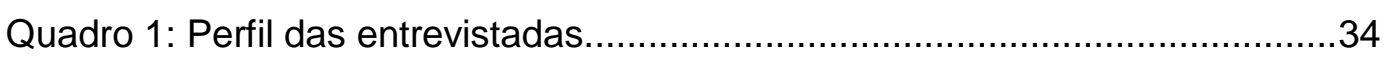

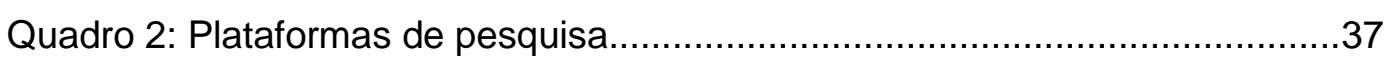

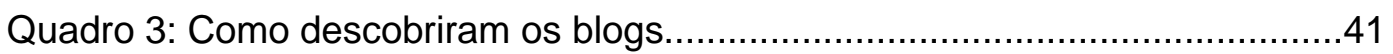

Quadro 4: Opinião acerca dos tipos de conteúdo dos blogs..............................45

Quadro 5: Conteúdo procurado nos blogs.....................................................46

Quadro 6: Informações compartilhadas pelas entrevistadas.............................48

Quadro 7: Descrição das blogueiras segundo as entrevistadas........................51 


\section{Introdução}

\subsection{Introdução ao tema e ao problema do estudo}

Ao longo das últimas décadas, o mundo empresarial vivenciou uma série de mudanças, entre elas o avanço da tecnologia e da industrialização, que provocaram uma maior competitividade de mercado. Cada vez mais vemos um número maior de empresas e, consequentemente, uma maior oferta de produtos. $\mathrm{O}$ consumidor passou a ter um maior poder de escolha frente às variadas opções de produtos, podendo selecionar os que the oferecessem melhor custobenefício. Diante da importância de atender às necessidades e desejos dos consumidores da melhor forma, surgiu o Marketing.

Segundo Kotler (1996, p. 29): "O Marketing evoluiu de suas antigas origens de distribuição e vendas para uma filosofia abrangente de como relacionar dinamicamente qualquer organização ao seu mercado". Isto é, as empresas reconheceram a importância de estudar e compreender o mercado e seus consumidores para garantir a satisfação destes.

Existe mais de uma definição para o conceito de Marketing. Segundo a American Marketing Association (AMA, 2013), "Marketing é a atividade, conjunto de instituições e processos para criar, comunicar, entregar e trocar ofertas que tenham valor para consumidores, clientes, parceiros e sociedade em geral”. Já para Kotler (1996, p. 31), "marketing é a atividade humana dirigida para satisfação das necessidades e desejos, através dos processos de troca". Podese dizer então que marketing é um conjunto de ferramentas complementares utilizadas para atingir o mercado-alvo. Dessa forma, é importante compreender as razões que levam o indivíduo ao consumo de determinado produto a fim de atender às necessidades individuais dos consumidores para que as suas expectativas sejam atingidas.

Segundo Kotler e Keller (2012), existem diversos fatores que podem influenciar o comportamento de compra dos indivíduos. Entre os fatores que podem exercer influência na decisão de compra estão os fatores sociais como os grupos de referência, família, papéis sociais e status; fatores culturais como cultura, subcultura e classe social; fatores psicológicos como as necessidades, motivação, percepção, aprendizagem e memória; fatores pessoais tais como a 
idade, a ocupação, a personalidade, circunstâncias econômicas, estilo de vida e valores.

Para alcançar as suas expectativas uma empresa deve ficar atenta, não só para novas oportunidades e novos mercados, mas também às mudanças do comportamento do consumidor e, então, traçar estratégias para se beneficiar a partir dessas mudanças.

O avanço tecnológico e, principalmente, o surgimento da internet, colaborou para que o comportamento dos indivíduos passasse por mudanças substanciais nos últimos anos. Essa mudança está presente em vários aspectos e está, principalmente, ligada à facilidade de relacionamento gerada pelas novas possibilidades de comunicação. A internet está presente como fonte de informações desde a fase pré-compra até o pós-venda.

Independentemente da plataforma de geração de conteúdo - comunidades virtuais, redes sociais, blogs, entre outras - utilizada, essas ferramentas apresentam nova oportunidades para as empresas chegarem de forma mais rápida e eficaz aos seu público-alvo. Além disso, proporcionam maior facilidade de avaliação e comparação de alternativas.

Entre as plataformas já mencionadas, os blogs relacionados a moda, estilo e beleza têm conquistado cada vez mais adeptos, sendo por isso cada vez mais considerados como meio de compartilhamento de informação entre os consumidores. Segundo uma pesquisa realizada pela empresa de pesquisa e inteligência de mercado Sophia Mind (2010), em média 67\% das usuárias de internet afirmam buscar informações na rede sobre produtos ou serviços antes de comprá-los ou contratá-los. Em alguns mercados, a relação entre consumidora e produto é mais intensa. Na compra de produtos do segmento de beleza, $53 \%$ das mulheres procuram informações em sites de revistas ou especialistas antes de realizar a compra e $42 \%$ das mulheres ficam sabendo de novidades do mercado de beleza através da divulgação na internet. No pósvenda, este canal também tem um papel importante. No caso dos produtos de beleza, $62 \%$ das mulheres buscam dicas de como usá-los. Esses números mostram a relevância da internet na vida das mulheres.

Considerando-se o exposto, levantou-se a necessidade do entendimento de como hábitos de consumo referentes a produtos de beleza são impactados pelos blogs, em particular no comportamento de compra. A partir disso, levantase a seguinte questão: como os blogs relacionados a moda, beleza e estilo influenciam o comportamento de compra das consumidoras de produtos de beleza? 


\subsection{Objetivo do estudo}

Compreender a influência que os blogs relacionados a moda, beleza e estilo têm no comportamento de compra das consumidoras de produtos de beleza.

\subsection{Objetivos intermediários do estudo}

Como focos intermediários deste estudo têm-se:

- Investigar a percepção das mulheres acerca do fenômeno dos blogs relacionados a moda, beleza e estilo;

- Compreender como os blogs são usados como meio de pesquisa na fase de pré-compra;

- Estudar a influência dos blogs nas decisões de compra de produtos de beleza;

- Investigar mudanças no comportamento de compra motivadas pelo universo dos blogs relacionados a moda, beleza e estilo.

\subsection{Delimitação do estudo}

A partir da necessidade de buscar um foco para a pesquisa, optou-se, por escolher estudar a influência dos blogs voltados para o público feminino que tratam de moda, beleza e estilo. A escolha se deu por serem assuntos centrais dos blogs femininos e devido ao fato de blogs com essa temática serem plataformas de divulgação de produtos do segmento selecionado para a pesquisa: o de beleza. Esta pesquisa considerou as seguintes subcategorias de produtos de beleza: maquiagem e produtos de cuidado de pele, rosto, mãos e unhas.

Neste trabalho, delimitou-se ao perfil a ser utilizado na pesquisa e o mesmo foi selecionado a partir do pressuposto de que, ainda hoje, as mulheres são as que melhor tipificam o universo de compradores de produtos de beleza. As consumidoras entrevistadas possuem as seguintes características:

- Gênero feminino;

- Faixa etária: 18 a 35 anos;

- Acessar blogs de moda, beleza e estilo, pelo menos, uma vez ao mês. 
Em relação ao tema Comportamento do Consumidor, este trabalho foca na suposição que os blogs podem exercer influência na fase pré-compra, na tomada de decisão e na mudança no comportamento de compra dos produtos de beleza. Quanto ao aspecto temporal e geográfico, a pesquisa foi realizada no primeiro semestre de 2016, na cidade do Rio de Janeiro.

\subsection{Relevância do estudo}

A escolha do tema do presente trabalho baseia-se na sua atualidade e importância para o panorama empresarial. Levando em conta o crescente número de blogs de moda e beleza existentes, torna-se relevante explorar o papel que essas plataformas podem ter na decisão de compra.

A internet se tornou um centro de referência de informação de produtos de moda e beleza para consumidores. Alguns dos grandes diferenciais dos blogs são o potencial de interatividade e o feedback quase instantâneo acerca da opinião do público. Dessa forma, os blogs passaram a ser um dos principais veículos de comunicação na internet, além de promoverem a democratização do acesso a informação.

É importante ressaltar que a internet não alterou apenas o comportamento do consumidor, mas também o comportamento das empresas. A ampla concorrência e o elevado nível exigência dos clientes reforçaram a necessidade dos gestores de se atualizar sobre as novidades do mercado. As empresas também podem utilizar os blogs como ferramenta para divulgação dos seus produtos e/ou serviços, captação de clientes, fidelização, entre outros. O marketing digital se tornou um investimento relevante e necessário, já que os consumidores utilizam internet em parte significativa de seu tempo. Portanto, o interesse pelo tema escolhido decorre da importância dessa plataforma para as empresas.

Segundo dados referentes a pesquisa da Nielsen IBOPE (2014), 120,3 milhões de pessoas têm acesso à internet no país. O número é $18 \%$ maior que a estimativa divulgada no primeiro trimestre de 2013 e 14\% maior que a última divulgação com relação ao segundo trimestre de 2013. Ao dividir em faixas etárias os brasileiros com acesso, o maior grupo é o de 25 a 34 anos de idade, que representa $22 \%$ do total, conforme mostra a Figura 1. 
Figura 1 - Distribuição do número de pessoas no Brasil com acesso segundo a faixa etária no primeiro trimestre de 2014.

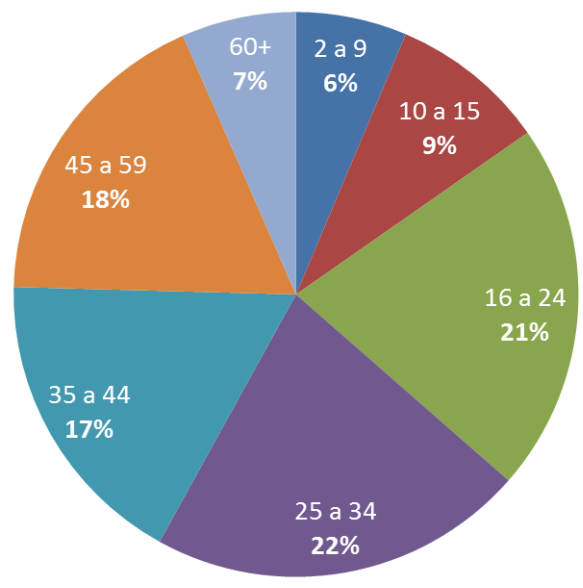

Fonte: Nielsen, $2014 . \quad$ IBOPE

Em 2015, a agência de marketing social We Are Social divulgou o relatório Digital, Social e Mobile que mostra as estatísticas completas de uso de internet em 2014. Segundo o estudo o Brasil é o terceiro país no mundo em que a população passa mais tempo na internet. Além disso, o brasileiro passa, em média, quase o dobro de tempo na internet do que na televisão. E, enquanto está navegando, mais da metade do tempo é passado nas mídias sociais.

Figura 1 - Tempo gasto com mídias sociais

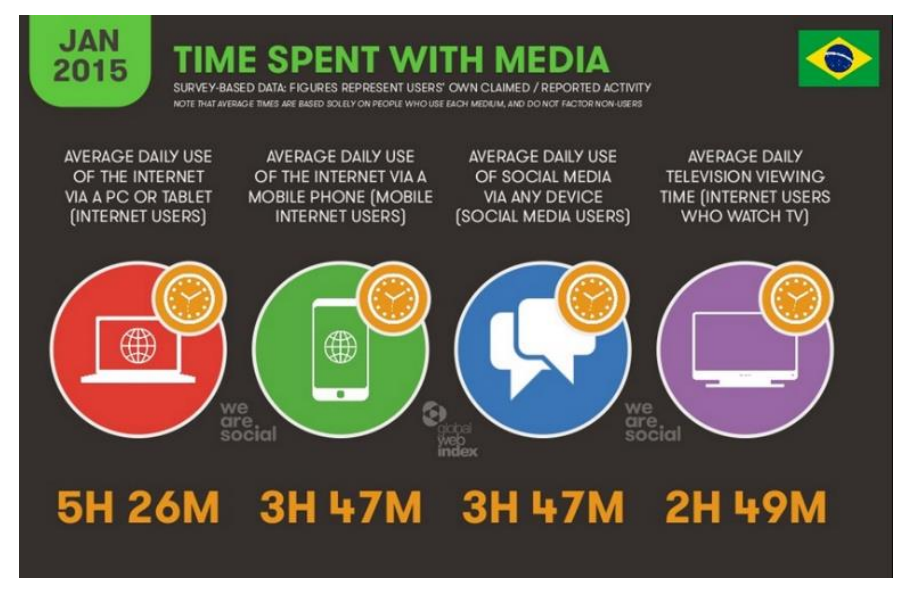

Fonte: We are Social, 2015.

Tendo em vista os dados expostos, os resultados obtidos neste estudo podem ser úteis na condução das diretrizes das estratégias de comunicação e marketing das empresas, em particular de produtos relacionados a moda, estilo e beleza. 


\section{Referencial teórico}

Neste capítulo são apresentados e discutidos aspectos conceituais e estudos relacionados ao tema e estudo em investigação e que servem de base para a análise realizada.

\subsection{Comportamento do consumidor}

Atualmente, o consumidor possui uma ampla variedade de produtos, marcas, lojas e meios para realizar suas compras. Entender o comportamento do consumidor se tornou fundamental para as empresas. As empresas que têm a habilidade e capacidade não só de atrair clientes, mas também de retê-los, têm maiores chances de serem bem-sucedidas.

Sob o ponto de vista de Hawkins et al. (1998), o comportamento do consumidor é um processo multidimensional complexo, tendo como essência a interdisciplinaridade combinando elementos de diversas áreas de conhecimento, tais como economia, antropologia, marketing e psicologia. (MOWEN; MINOR, 2003). Deste modo, percebe-se que entender o comportamento do consumidor não é tão simples e para lográ-lo é necessário analisar a sua importância, não apenas por permitir a compreensão do próprio comportamento de compra, mas também por possibilitar o entendimento do processo de tomada de decisão.

De acordo com Solomon (2011), o comportamento do consumidor envolve estudar o conjunto de processos envolvidos ao comprar, usar ou descartar um produto e/ou serviço a fim de satisfazer desejos e necessidades. Já Mowen (1995, p. 5) define o comportamento do consumidor como "o estudo das unidades de compradoras e do processo de troca envolvidos na aquisição, no consumo e na disposição de mercadorias, serviços, experiências e ideias". Estudar o comportamento do consumidor, portanto, é compreender como todo o processo de consumo ocorre, incluindo diversos fatores que influenciam 0 consumidor antes, durante e depois da compra.

As empresas que têm como objetivo ser bem-sucedidas no atual cenário competitivo não têm outra escolha a não ser a de buscar compreender o consumidor (e todos os fatores que influenciam suas decisões de compra) e atender melhor aos seus desejos e necessidades quando comparadas às 
empresas concorrentes. A partir da compreensão do comportamento do consumidor, os profissionais de marketing têm a possibilidade de fazer previsões sobre as expectativas de consumo e, assim, planejar sua estratégia mercadológica.

\subsubsection{Fatores de influência no comportamento do consumidor}

São vários os determinantes e fatores que influenciam e moldam a tomada de decisão do consumidor. Para Kotler e Armstrong (2008), há quatro fontes principais que influenciam o comportamento do consumidor:

- Fatores culturais - cultura, subcultura e classe social;

- Fatores sociais - grupos de referência, família, papéis e status;

- Fatores pessoais - idade, ocupação, renda, estilo de vida, personalidade e autoimagem;

- Fatores psicológicos - motivação, percepção, aprendizagem, crenças e atitudes.

Engel, Blackwell e Miniard (2000), agruparam esses fatores de forma similar. Diversos fatores que englobam aspectos culturais, sociais, individuais (pessoais) e psicológicos, foram divididos em três categorias:

- Diferenças individuais - recursos, conhecimentos, atitudes, motivação, personalidade, valores e estilo de vida;

- Influências ambientais - cultura, classe social, influência pessoal, família e situação;

-Processos psicológicos - processamento de informação, aprendizagem e mudança de atitude e comportamento.

Em outras palavras, o comportamento de compra é influenciado por fatores que podem ser culturais, pessoais e sociais; entre eles, os fatores culturais exercem maior influência. O consciente do comprador é permeado por estímulos ambientais e de marketing, e um conjunto de fatores psicológicos aliados a determinadas características pessoais levam o consumidor a processos de decisão de compra. O objetivo do marketing é compreender o que ocorre no consciente desse comprador na lacuna entre o estímulo e a decisão de compra (KOTLER; KELLER, 2012). 


\subsubsection{Processo de tomada de decisão}

Existem pontos de concordância entre diversos autores acerca das etapas do processo de tomada de decisão. Para grande parte, o consumidor se sujeita a vários estágios que antecedem a compra, compondo o processo de tomada de decisão.

O fluxo genérico mostrado na Figura 3 proposto por Mowen (1995) descreve o processo do comportamento de compra de forma similar a Solomon e Hawkins et al::

Figura 2 - Processo de decisão de compra

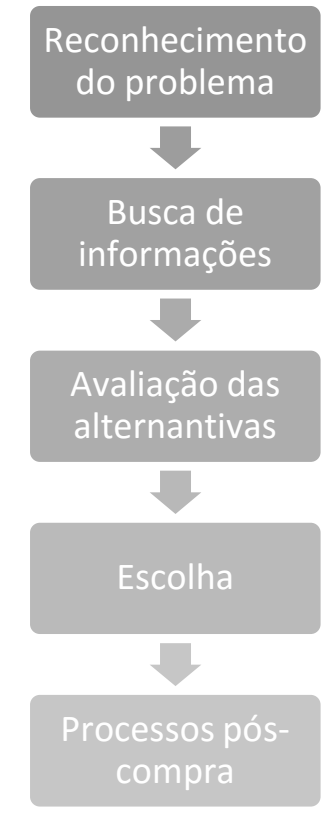

Fonte: Mowen (p. 422, 1995).

Já Engel et al. (2000) dividiram o processo em sete, acrescentando o consumo e descarte. As etapas 2,3, e 4 - busca de informações, avaliação das alternativas e escolha, respectivamente - são foco do presente e são melhor detalhadas a seguir.

\subsubsection{Busca de informação}

Após reconhecer um problema, o consumidor precisa de informações adequadas para chegar a uma solução. Segundo Solomon (2011), esta etapa é o processo pelo qual o consumidor pesquisa o ambiente em busca de dados 
adequados para a tomada de decisão. Para isso, o consumidor recorre a diferentes meios, a fim de obter informações.

A busca por informações pode ser interna ou externa. Inicialmente, recorre-se à informação interna, envolvendo conhecimento prévio, memória e experiências do consumidor. Já a busca externa envolve fontes externas e pode incluir: opiniões, atitudes, comportamentos de amigos, vizinhos, familiares, e, cada vez mais, desconhecidos conectados via internet; informação em livros, panfletos, artigos; experiências diretas com o produto por meio de inspeção ou experimentação; publicidades e pessoal de venda. (HAWKINS; BEST; CONEY, 1998)

\subsubsection{Avaliação de alternativa pré-compra}

A terceira etapa do modelo genérico de tomada de decisão corresponde ao processo no qual o consumidor identifica as diferentes opções capazes de solucionar o problema que iniciou o processo de decisão. Ao comparar as opções, o consumidor pode formar atitudes, crenças e intenções em relação às diferentes alternativas (MOWEN, 1995). É por meio da avaliação das alternativas que o consumidor obtém as informações necessárias e avalia os benefícios que o produto pode trazer em comparação aos benefícios procurados por ele.

Durante a avaliação de alternativa, segundo Engel, Blackwell e Miniard (2000), o consumidor utiliza critérios de avaliação que são os padrões e especificações usados para comparar diferentes produtos e marcas. Esses critérios são os benefícios almejados na compra e são expressos na forma de atributos preferidos que são influenciados pelas diferenças individuais e ambientais. Solomon (2011), ressalta outro ponto importante relacionado aos critérios: eles têm mais peso quando os produtos diferem entre si.

Outro ponto a ser destacado é a relação desta fase ao nível de envolvimento do consumidor em relação ao produto. Segundo John Antil (1984, apud Engel, Blackwell e Miniard, 2000, p. 106): "Envolvimento é o grau de importância pessoal percebida e/ou interesse evocado por um estímulo (ou estímulos) dentro de uma situação específica". Entre os fatores que influenciam o nível de envolvimento de um consumidor estão: o tipo de produto considerado; as características da informação recebida pelo consumidor; o contexto situacional e, por fim, as caraterísticas inerentes ao consumidor, como a personalidade (MOWEN; MINOR, 2003). 
Portanto, considerando os diversos fatores que exercem influência nesse aspecto, nem todos os indivíduos apresentam o mesmo grau de envolvimento. Quanto maior for o envolvimento, maior será a motivação do consumidor e o tempo dedicado ao processo de decisão. Quanto menor for o envolvimento, menor será a motivação e o tempo despendido na decisão.

\subsubsection{Compra}

A compra representa a etapa na qual o consumidor, por meio do seu conhecimento prévio, faz a sua escolha para atender à necessidade identificada na primeira etapa. Kotler e Armstrong (2008) ressaltam que o modelo genérico de tomada de decisão visto anteriormente considera que os consumidores passam por todos os estágios em sequência. Entretanto, este não é o caso para as compras de baixo envolvimento e nas compras por impulso, situações em que os consumidores podem passar por cima ou inverter alguns estágios. Ou seja, a tomada de decisão do consumidor varia conforme o tipo de decisão de compra.

As regras de decisão se subdividem em simples e complexas. As simples são utilizadas quando a compra é rotineira, ou para a escolhas de produtos repetitivos, que têm pouca relevância ou baixo envolvimento. Já as complexas, segundo Solomon (2011), ramificam-se em compensatórias e não compensatórias.

Para Solomon (2011), as regras de decisão não-compensatórias são uma espécie de atalho para a escolha do produto, ou seja, se o consumidor determina um atributo como sendo muito importante para a escolha de um produto, basta o produto ter baixa posição neste atributo para que o produto seja descartado como alternativa, independentemente de qualquer outro ponto forte que ele possa ter. Em contrapartida, as regras de decisão compensatórias, diferenciam-se das não-compensatórias uma vez que dão ao produto uma chance de compensar suas falhas, isto é, um ponto fraco em um atributo pode ser compensado pelo ponto forte em outro atributo. As regras compensatórias são separadas em dois tipos: aditiva simples que é escolha influenciada pelo número de atributos positivos e aditiva ponderada que combina a análise do número de atributos positivos com sua importância (SOLOMON, 2011). 
Tendo como base o envolvimento do consumidor e as diferenças entre as marcas, Kotler e Armstrong (2008) identificam quatro tipos de comportamento de compra apresentados:

Figura 4: Quatro tipos de comportamento de compra

Alto envolvimento

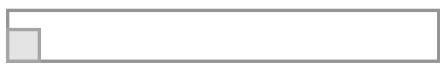

Diferenças significativas entre as marcas

Poucas diferenças entre as marcas

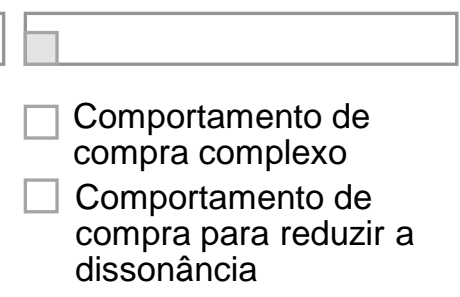

Baixo envolvimento

Comportamento de
compra que busca
variedade
Comportamento de
compra habitual

Fonte: Adaptado de Kotler e Armstrong (p.126,2008)

De acordo com Kotler e Armstrong (2008), o comportamento de compra complexo caracteriza-se pelo nível de envolvimento elevado do consumidor na compra e pela percepção de diferenças significativas entre as marcas. Este tipo de comportamento pode se manifestar quando o produto tem custo elevado, envolve risco, ou quando a compra é realizada com baixa frequência.

Já o comportamento de compra para reduzir a dissonância acontece quando o consumidor está bastante envolvido na compra e percebe pouca diferenciação entre as marcas. O consumidor pesquisará as opções disponíveis por se tratar de uma compra pouco frequente envolvendo um produto caro e com risco. Optará pelo produto que possua algum diferencial, como o preço.

O comportamento que busca variedade ocorre quando o consumidor apresenta um baixo nível de envolvimento na compra e diferenças significativas entre as marcas. Diante disso, os consumidores mudam de marca frequentemente, mais devido à variedade do que à insatisfação com o produto.

Por fim, o comportamento habitual de compra tem como característica o baixo envolvimento do consumidor e quando este percebe poucas diferenças significativas entre as marcas. Os consumidores escolhem um produto mais por hábito do que por lealdade à marca. Este tipo de comportamento costuma envolver produtos de baixo custo. 


\subsubsection{Grupos de referência}

A decisão de consumo está diversos elementos que influenciam o comportamento. Entre os fatores influenciadores estão os fatores sociais que envolvem os grupos de referência.

Os grupos de referência são pessoas que influenciam os consumidores na decisão de compra. Segundo Solomon (2011, p. 408) o grupo de referência é "um indivíduo ou grupo, real ou imaginário, concebido como capaz de ter relevância significativa para as avaliações, aspirações ou comportamento de um indivíduo". Já Churchill e Peter (2003) afirmam que os grupos de referência são indivíduos que influenciam os sentimentos, pensamentos e comportamento dos consumidores. Assim, os grupos de referência podem ser entendidos como aquelas pessoas ou grupos dos quais os consumidores buscam orientação sobre seu comportamento e valores, além de aprovação.

A maioria das pessoas sofre influência de vários grupos de referência. Para alguns, podem ser os amigos, profissionais de sucesso em sua área de atuação, celebridades com as quais se identificam, ou, ainda, a própria família.

A divisão dos grupos proposta por Engel, Blackwell e Miniard (2005) separa os grupos de referência em: primários e secundários, aspiracionais e dissociativos, formais e informais, e virtuais.

Os grupos primários são os de maior impacto e maior influência, sendo que os indivíduos mantêm contato face a face com os seus membros e a interação entre seus participantes ocorre com frequência. O principal exemplo de grupo primário é a família. Os grupos secundários, por sua vez, também têm contato face a face, porém a interação é menos frequente. As opiniões do grupo têm menos impacto que as do grupo primário. Associações profissionais, organizações comunitárias e sindicatos são exemplos dos grupos secundários.

Embora os grupos aspiracionais exerçam influência, em geral, de forma indireta sobre o consumidor, podem ter um papel significativo na decisão de compra. Esses grupos "exibem um desejo de adotar as normas, os valores e os comportamentos de outros com quem o indivíduo espera associar-se". (ENGEL; BLACKWELL; MINIARD; 2000, p.461). Em contrapartida, os grupos dissociativos compõem os grupos em que a associação ou contato é evitado.

Os grupos formais são caracterizados pela organização formal, com estrutura definida e membros conhecidos. A influência exercida sobre 0 comportamento varia de acordo com a motivação do indivíduo. Os principais tipos de grupos formais são as igrejas, organizações de serviço comunitário e 
fraternidades. Já os grupos informais têm menos estrutura e tem maior chance de serem baseados na amizade e em interesses comuns. Embora suas normas raramente aparecem por escrito, podem ser tão rígidas quanto as dos grupos formais. Neste caso, a influência do grupo pode ser forte quando houver desejo por aceitação social.

Por fim, os grupos virtuais são aqueles nos quais os integrantes mantêm contato por meio da internet, em diversas formas de interação, como: fóruns, blogs, redes sociais como Facebook etc.

Segundo Solomon (2011), a influência pelos grupos de referência pode ocorrer de três maneiras: informativa, utilitária e expressiva de valor. A influência informativa ocorre quando o consumidor busca e aceita conselhos de indivíduos que têm maior conhecimento do que ele a respeito das características do produto que deseja adquirir. O tipo de influência utilitária acontece quando o indivíduo é influenciado pelas preferências das pessoas com quem interage socialmente. A influência expressiva de valor ocorre quando o indivíduo se submete à influência de terceiros com os quais ele mantém uma relação de identificação ou aspira ter esta identificação. A decisão do consumidor pode ser influenciada pelo desejo em promover o seu status e sua imagem perante o grupo, ou ainda pela identificação com pessoas que são admiradas.

\subsubsection{Líderes de opinião}

Um conceito importante associado a grupos de referência é o de líderes de opinião. São pessoas que exercem influência especial, acima da média do grupo e são fontes de informação extremamente valiosas por possuírem poder social.

Solomon (2011) caracteriza os líderes de opinião como tecnicamente competentes, socialmente ativos e altamente ligados a suas comunidades, tendência a ser semelhantes ao consumidor em termos de valores e crenças. Outro ponto destacado pelo autor é que os líderes de opinião, muitas vezes, são os primeiros a adquirir um novo produto, absorvendo grande parte do risco, e consequentemente, diminuindo a incerteza para outros. Além disso, a experiência prática dos líderes torna mais provável que compartilhem informações positivas e negativas a respeito do produto. 


\subsubsection{Autoconceito}

Por autoconceito entende-se o conjunto de crenças que uma pessoa tem a respeito dos seus próprios atributos e no modo como os avalia (SOLOMON, 2011).

Devido ao fato das pessoas terem necessidade de se comportarem de forma consistente com o seu autoconceito, essa percepção de si faz parte das bases para a personalidade. Tal comportamento auto consistente ajuda a pessoa a manter a sua autoestima (MOWEN,1995).

Mowen (1995) identifica oito tipos de autoconceito, mostrados na Figura 5:

Figura 5 - Tipos de Autoconceito

\begin{tabular}{l|l}
\hline Eu Real & $\begin{array}{l}\text { Como a pessoa vê a si própria } \\
\text { Eu Ideal }\end{array}$ \\
Eu Social & $\begin{array}{l}\text { Como a pessoa gostaria de ver a si própria } \\
\text { Como a pessoa acha que os outros a veem }\end{array}$ \\
Eu Social ideal & Como a pessoa gostaria que os outros a vissem \\
Eu Esperado & Uma autoimagem que se situa entre o eu real e o eu ideal \\
Eu Situacional & Autoconceito em uma situação específica \\
Eu Estendido & $\begin{array}{l}\text { Autoconceito que inclui a influência das posses pessoais na } \\
\text { autoimagem }\end{array}$ \\
Eus Possíveis & $\begin{array}{l}\text { O que pessoa gostaria de tornar-se, poderia vir a ser ou tem } \\
\text { medo de vir a ser }\end{array}$
\end{tabular}

Fonte: Mowen (p. 250,1995)

Uma distinção pode ser feita entre o autoconceito (identidade), e autoavaliação (autoestima). Autoconceito, normalmente, se refere ao conceito de que indivíduos têm de si próprios como seres físicos, sociais e espirituais ou morais (Mecca, Smelser e Vasconcellos,1989). Já a autoestima é um conjunto de sentimentos e pensamentos que o indivíduo tem em relação a si mesmo. Refere-se a uma representação pessoal que tem a ver com a positividade do autoconceito de uma pessoa. (Solomon, 2011). Para Maçola, Vale e Carmona (2010), pode ser considerada como um juízo de valor que uma pessoa tem em relação a si mesma e começa a ser moldada na infância e influencia na relação do indivíduo consigo mesmo e com terceiros, na percepção de acontecimentos e também no próprio comportamento. 
Na visão de Rosenberg (1985, apud Mecca, Smelser e Vasconcellos, p. 36), o autoconceito é amplamente definido como o conjunto de pensamentos e sentimentos que o indivíduo tem em relação a si mesmo como objeto. Autoestima, no entanto, tem sido referido como uma autoavaliação geral do indivíduo, o "eu" como um objeto de conhecimento.

\subsubsection{Imagem corporal}

A aparência física de um indivíduo é uma parte considerável de seu autoconceito. A imagem corporal de uma pessoa diz respeito à avaliação subjetiva do consumidor sobre seu eu físico. Assim como no caso do autoconceito geral, essa avaliação pode ser distorcida em relação à realidade. $A$ catexia corporal é o agrupamento de sentimentos de uma pessoa em relação ao seu corpo. Um estudo revelou que, muitas vezes, as impressões positivas de uma pessoa acerca de certas partes do seu corpo estão relacionadas com o uso de produtos cosméticos. A satisfação das pessoas com a sua imagem física apresentada a terceiros é afetada pelo quanto essa imagem é valorizada por sua cultura, em outras palavras, o grau de satisfação está relacionado ao ideal de beleza. (SOLOMON, 2011).

\subsection{0 mercado de produtos de beleza e seu consumo}

O setor da beleza representa um dos mercados de bens de consumo mais importantes do Brasil. O cuidado com o corpo tem conquistado cada vez mais adeptos entre mulheres e homens de todas as idades, hoje, a lista de produtos de beleza que são indispensáveis está bem mais ampla. A indústria de beleza caracteriza-se por oferecer uma diversidade de produtos aos consumidores, tais como: maquiagem, produtos de cuidados de rosto, pele e cabelo, assim como produtos de cuidados de unhas e mãos, entre outros.

Segundo o relatório da firma de pesquisa britânica Mintel, Brazilian Lifesyles 2015 (Estilos de Vida do Consumidor Brasileiro), que engloba todos os setores de consumo do país, apesar do Brasil enfrentar uma crise econômica, alguns setores apresentarão melhor desempenho que outros. De acordo com o relatório, Beleza e Cuidados Pessoais são setores que devem ter um crescimento estável nos próximos anos.

A agência avalia que o mercado de Beleza e Cuidados Pessoais deve continuar crescendo, ainda que com taxas moderadas, quando comparadas com 
as taxas dos últimos anos. O consumo de produtos do setor avançará com menos força no Brasil devido ao aumento da inflação e dos impostos, ao maior índice de desemprego e à retração da economia. Segundo a firma de consultoria, um dos motivos que levam as pessoas a gastarem dinheiro em produtos de beleza nos momentos de crise econômica, é a priorização da autoestima.

Em relação ao mercado mundial de Higiene Pessoal, Perfumaria e Cosméticos, conforme dados do Euromonitor de 2014, o Brasil ocupa a terceira posição, conforme mostrado na Figura 6:

Figura 6 - Mercado mundial de Higiene Pessoal, Perfumaria e Cosméticos

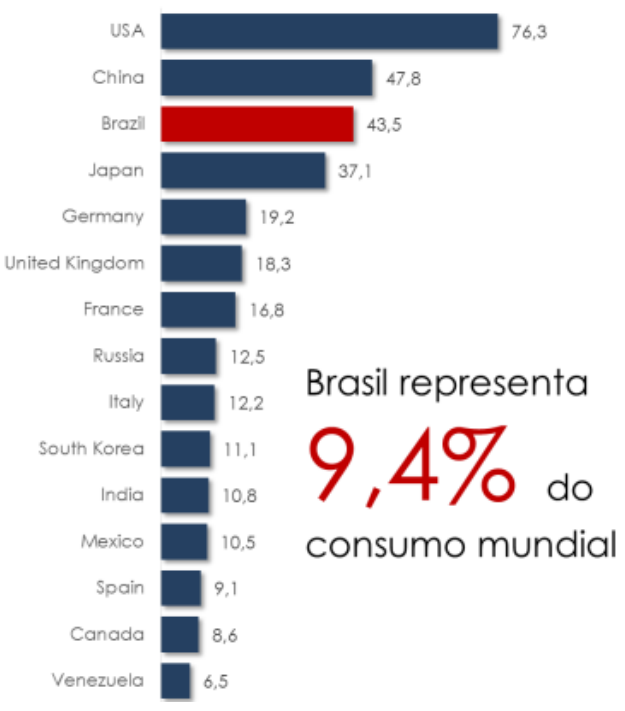

Fonte: ABIHPEC, 2014.

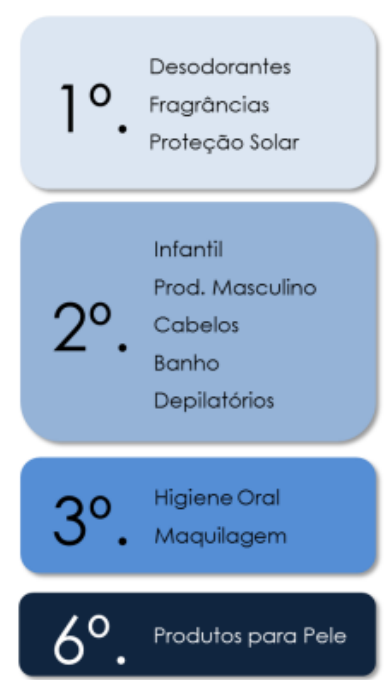

Euromonitor

Segundo dados da pesquisa realizada pela empresa Sophia Mind (2009), as mulheres estão passando por grandes mudanças culturais, sociais e no comportamento e precisam ser entendidas profundamente para que se possa estabelecer uma comunicação efetiva e conveniente com elas. $O$ objetivo do estudo foi avaliar a satisfação das mulheres com a sua aparência e entender de que forma ocorre o consumo de produtos e tratamentos de beleza.

Dentre os principais resultados da pesquisa destaca-se:

- 56\% das mulheres estão insatisfeitas com sua aparência;

- A opinião de terceiros é importante para ela se sentir bem;

- $79 \%$ das mulheres usam produtos de beleza. Entre os mais usados estão os produtos para o cabelo, cremes hidratantes e maquiagens;

- Qualidade e preço são os atributos mais importantes na decisão de compra. A indicação de profissional de confiança também é muito relevante; 
- O gasto médio mensal com serviços e tratamentos de beleza é maior do que o gasto médio com produtos de beleza;

- Em uma situação de crise econômica, a ida ao salão de beleza seria o segundo item a ser cortado do orçamento. A compra de produtos de beleza é um dos últimos itens indicados ao corte;

- As mulheres ficam sabendo acerca das novidades de produtos por meio de amigas e profissionais da área de beleza que, ao mesmo tempo, indicam o uso de produtos específicos;

- A publicidade na internet e redes sociais são relevantes na decisão de compra.

Somente $12 \%$ das mulheres entrevistadas não utilizam a internet para buscar informações acerca dos produtos de beleza. Para as demais, 88\%, a internet possui diversas finalidades na busca de informações e no processo de compra. A leitura de dicas de como usar os produtos de beleza - encontrada em sites com conteúdo feminino, redes sociais, etc. - é a principal atividade realizada na internet o que mostra a relevância dos blogs. Além disso, outras atividades relacionadas ao conteúdo existente nos blogs fazem parte do papel da internet do consumo de produtos de beleza conforme mostra a Figura 7.

Figura 7 - Papel da internet no consumo de produtos de beleza

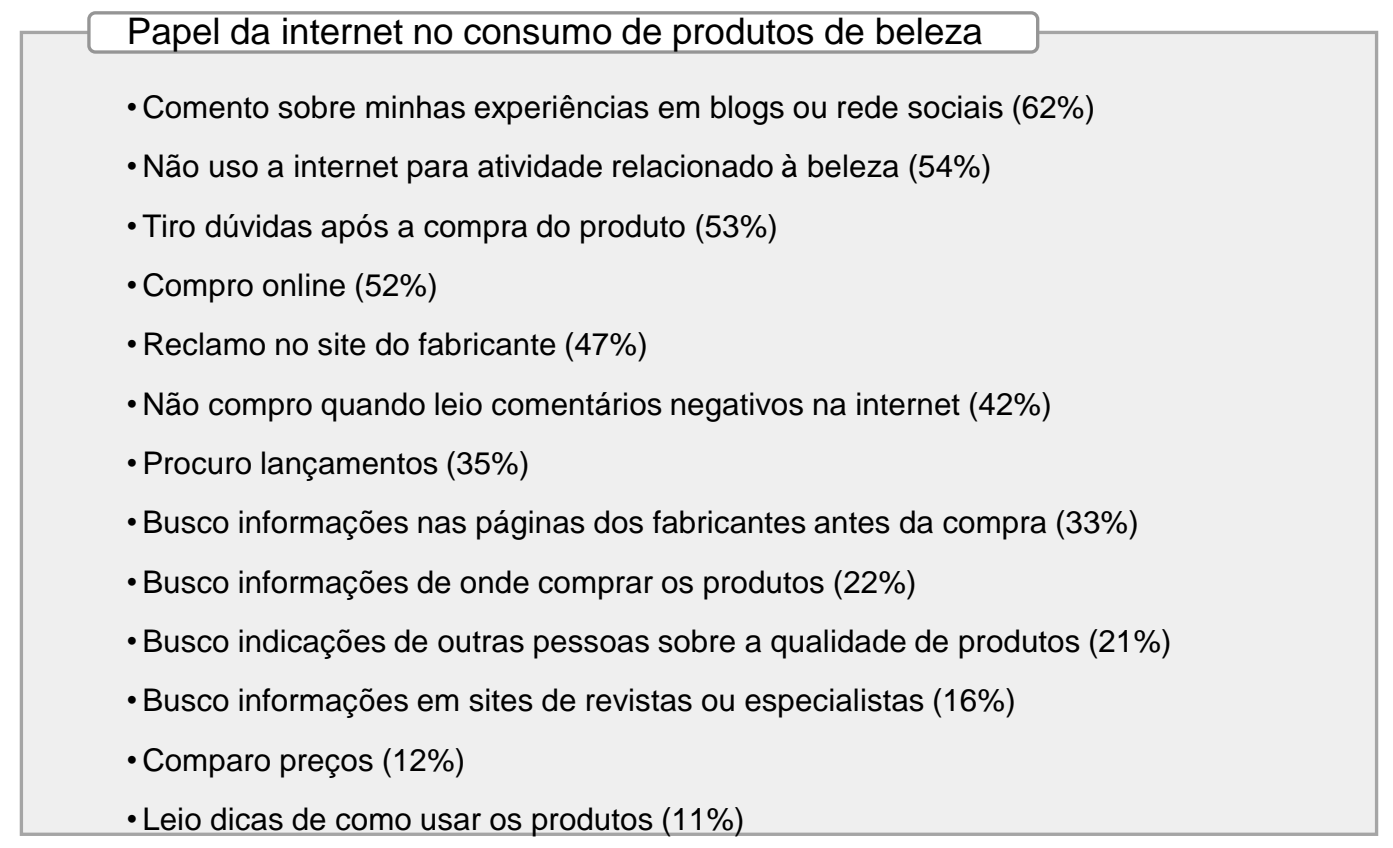

Fonte: Adaptado de Sophia Mind, 2009.

Concluiu-se que a insatisfação das mulheres com a aparência ou a vontade de melhorar uma determinada parte do corpo mostram o potencial do mercado de beleza. A fim de aproveitar esse potencial do mercado, é importante 
que as empresas tracem uma estratégia clara de comunicação e marketing de suas marcas, uma vez que a concorrência é muito grande. Na disputa pela conquista de consumidoras, as empresas devem estar atentas não só à consumidora final, mas também às pessoas que podem influenciar uma compra, como amigas e profissionais da área conforme relatado. A indicação dessas pessoas é muito importante no processo de decisão de compra de um produto de beleza, portanto, a inclusão dos formadores de opinião na estratégia de divulgação da marca é essencial.

Independentemente do comportamento de consumo das mulheres, suas rotinas, crenças e seu posicionamento perante à sociedade são os fatores que devem ser levados em consideração para defini-las. O estudo "Beauty4U - As quatro dimensões da beleza feminina" (2015), realizado pela agência Grey Brasil identifica os perfis de mulheres diferentes, segundo seus valores e forma de se relacionar com a beleza. Segundo a diretora-geral de Planejamento, Sumara Osório, a segmentação mostra as mudanças na autoimagem feminina, rotinas de beleza, preocupações com a aparência, e outros comportamentos.

Após analisarem dois eixos, padrão de beleza e motivação, os pesquisadores encontraram dois tipos de mulheres: a inner directed - aquela que é motivada pelas próprias emoções -, e a outer directed - aquela que está preocupada com o que os outros pensam ao seu respeito. Além de compreender como as consumidoras agem, o estudo também buscou entender se a beleza é uma consequência ou um objetivo e com isso foram identificados quatro tipos de perfis. Cada tipo de mulher foi batizado com nomes de peças do vestuário feminino: Jeans, Legging, Leather e Ripped.

Figura 8 - Quatro tipos de perfis de mulheres EXTERIOR (COMO ELA É VISTA É MAIS IMPORTANTE)

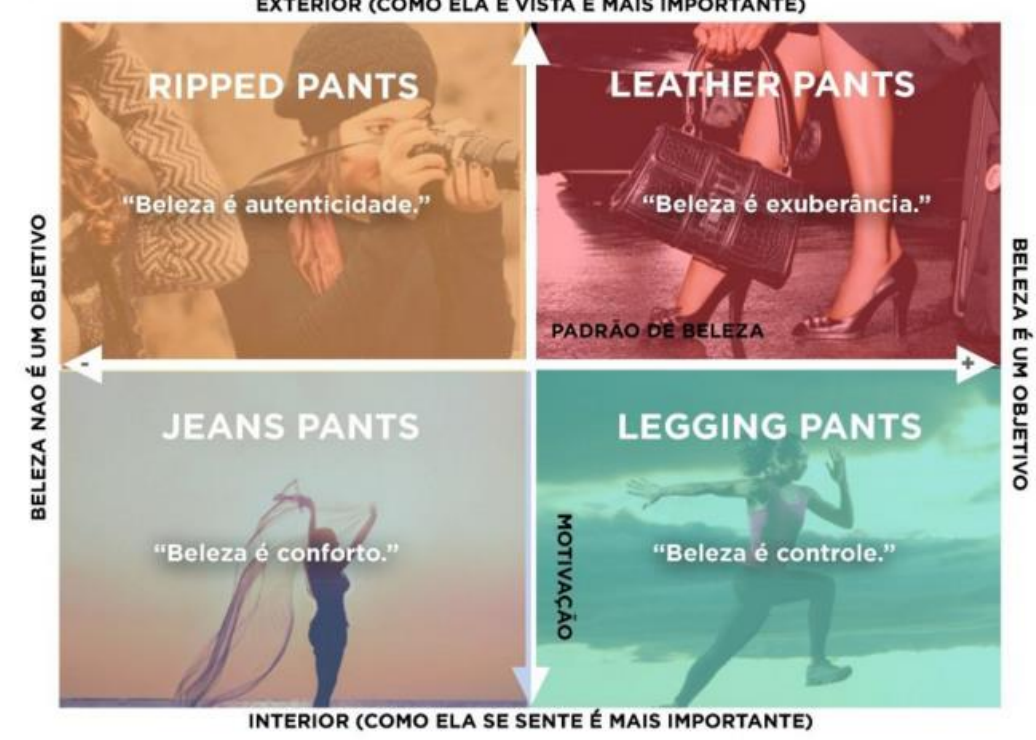

Fonte: Pulse Brasil, 2015. 
- Jeans - O maior grupo entre os quatro, representando $46 \%$ das informantes. Possuem valores relacionados a beleza, como conforto, espontaneidade e equilíbrio. Priorizam a praticidade no seu dia a dia e a maioria não está disposta a abrir mão do que gosta pela estética;

- Legging - 24\% das informantes. A preocupação com a beleza adquire aspectos cada vez mais saudáveis. Possuem valores como determinação, energia e controle, bem como hábitos saudáveis;

- Leather $-16 \%$ das informantes. Possuem em comum os valores de exuberância, rigor e encanto. São as que fazem mais sacrifícios para ficar bonitas.

- Ripped Pants (calça desfiada) - 14\% das informantes. Originalidade, ousadia e atitude definem este grupo. Gastam muito dinheiro e pagam qualquer preço por um produto de beleza que realmente queiram.

Uma das conclusões do estudo é que, com o acesso à informação mais democrático, as mulheres pesquisam dezenas de opções para comprar o que as torna mais cautelosas e menos impulsivas na hora de realizar uma compra. $\mathrm{Na}$ média geral, entre os quatro perfis, $28 \%$ declaram que compram por impulso, sendo o perfil Jeans o mais baixo e o Leather o mais alto. Por outro lado, a média de mulheres que procuram o maior número de informações possível antes de comprar é bem elevada, representando $72 \%$, e o perfil que mais se informa é o Legging e o que menos se informa é o Jeans.

É importante ressaltar que um perfil influencia o outro. O estudo também diz que nenhuma mulher é $100 \%$ um dos quatro perfis. Embora haja uma tendência mais forte para um tipo, todas possuem características dos outros três tipos.

\subsection{Influência da internet no comportamento do consumidor}

\subsubsection{A internet como canal de informação}

Além de proporcionar inúmeras vantagens aos seus usuários, a internet também motivou algumas mudanças no seu processo de decisão de compra. Com a popularização da internet, o acesso a informação passou a ser mais amplo e ainda gratuito, assim, oferecendo facilidades e conveniência aos consumidores relacionadas ao processo de compra. Como descrito por Mikalef, Giannakos e Pateli (2013, p.23), "a internet é indiscutivelmente a maior e mais eficiente fonte de aquisição de informação". 
Um dos aspectos mais importantes para o uso da internet na realização de buscas de informação é a quantidade e a disponibilidade dos assuntos procurados (Wolfinbarger e Gilly, 2001). Em relação aos benefícios proporcionados pela internet, segundo Moon (2004), um dos principais é a conveniência aos consumidores para a busca de informação na fase précompra, a avaliação das alternativas, a compra e uso dos produtos tangíveis ou intangíveis de forma mais eficaz e eficiente a fim de satisfazer suas necessidades. Assim, os consumidores podem reunir informação acerca do produto em que estão interessados e reduzir o risco na sua tomada de decisão.

Além da importância de encontrarem facilmente a informação que desejam, grande parte dos consumidores também considera importante a localização, de maneira simples, dessa informação em um website, o que aumenta a sensação de controle (Wolfinbarger e Gilly, 2001).

\subsubsection{Boca-a-boca e boca-a-boca eletrônico}

Quando os consumidores querem adquirir um novo produto ou serviço, eles tendem a buscar informações de membros da família, amigos e outros. Portanto, para muitos consumidores, informações que são recebidas de terceiros, conhecida também como word-of-mouth (WOM), são uma importante fonte de informação acerca de produtos e marcas.

De acordo com Solomon (2011, p. 424), a comunicação boca-a-boca é "a informação sobre produtos transmitida de indivíduos para indivíduos". Isto é, a comunicação boca-a-boca pode ser definida como uma forma de comunicação entre os consumidores com base em suas experiências pessoais e impressões de um produto ou serviço.

Conforme visto anteriormente, com o advento da Internet, houve uma mudança de paradigma por meio da democratização do acesso à informação e devido à oportunidade de os consumidores compartilharem suas experiências relacionadas à compra e consumo de um produto e/ou serviço. Algumas plataformas como os blogs, redes sociais, websites e comunidades virtuais, contribuíram para essa mudança e assumiram um papel importante já que, tendo em vista que os consumidores procuram estar cada vez mais informados, essas plataformas tornaram-se um importante meio de comunicação e compartilhamento de informação online. O boca-a-boca eletrônico em plataformas web pode ser iniciada devido a um desejo de ajudar outros consumidores nas suas decisões de compra, e dessa forma, salvá-los de 
experiências negativas. Este tipo de comunicação pode incluir tanto experiências positivas como negativas (HENNIG-THURAU ET AL., 2004). Segundo Kulmala (2011), a comunicação boca-a-boca, geralmente, ocorre entre dois consumidores. Já a mensagem do boca-a-boca eletrônico é coproduzida por diversas pessoas no ambiente online, como websites, fóruns, blogs, entre outros.

Assim, a internet possibilita uma maior conectividade e interatividade, e suas plataformas e ferramentas sociais aceleram essas experiências de interação e comunicação (Amaral, 2012). Devido ao uso da internet como um meio de pesquisa e partilha de informação, e à interatividade proporcionada pela ferramenta, o consumidor passou a intervir mais, criando seu próprio conteúdo. Essa nova modalidade de consumidor é denominada prosumers. Isto é, os consumidores deixaram de ser simples consumidores de conteúdos e passaram a ser também produtores de conteúdos (RITZER e JURGESON, 2010).

Esse tipo de conteúdo, denominado User Generated Content - (UGC), é visto como um importante canal de informação. O motivo da comunicação boca a boca ser tão influente está relacionado com o fato das pessoas tenderem a ver os restantes dos consumidores como pessoas iguais a elas (Allsop et al., 2007), assim, esse tipo de comunicação tem um papel importante na decisão de compra dos consumidores.

\subsubsection{Blogs}

As mídias sociais são canais de relacionamento na internet onde existem variadas possibilidades de interação e participação entre os seus usuários. São ferramentas que tem como principais características a capacidade de gerar mídia espontânea, criar ou compartilhar conteúdo. Blogs, microblogs (Twitter), redes sociais (Facebook), fóruns, mensagens instantâneas, sites de compartilhamento de conteúdo multimídia (YouTube, Flickr, SlideShare, Vimeo, Pinterest), são alguns exemplos de mídias sociais.

Em 2009, segundo o relatório Global Faces and Networked Places divulgado pela Nielsen, as redes de relacionamento e blogs já eram a $4^{\underline{a}}$ atividade on-line mais popular, acima inclusive do e-mail pessoal. Entre os mercados mensurados pela Nielsen, a penetração dos acessos às redes de relacionamentos e blogs foram maiores no Brasil, onde $80 \%$ da audiência on-line acessa tais sites. A participação do tempo geral na internet nas redes de relacionamento e blogs também foram maiores no Brasil, onde o tempo gasto nestes tipos de sites é de quase um em quatro minutos. 
Até o final de 2011, NM Incite - joint-venture composta pela Nielsen e McKinsey -, rastreou mais de 181 milhões blogs ao redor do mundo, um aumento de 36 milhões registrados em 2006. Há duas outras informações relevantes divulgadas: as mulheres constituem a maioria dos blogueiros, e metade dos blogueiros têm idade entre 18-34 anos; blogueiros estão ativos em toda a mídia social: são duas vezes mais propensos a publicar/comentar em sites de vídeos gerados pelo consumidor, como o YouTube, e quase três vezes mais propensos a postar em fóruns.

Portanto, conclui-se que os blogs são uma plataforma importante de interação virtual e de disseminação de eWOM. Devido ao surgimento da web 2.0, os blogs tornaram-se uma importante ferramenta de marketing.

Zago (2008, p.2) define os blogs como:

Veículos de publicação digital, comumente associados à ideia de diários virtuais, nos quais um ou mais autores publicam textos, geralmente sobre uma temática específica, em ordem cronológica inversa e de forma frequente. A simplicidade com que se pode publicar textos em um blog fez com que a ferramenta alcançasse uma relativa popularidade no mundo todo.

Os blogs têm se tornado um meio de comunicação cada vez mais popular na world wide web, e são vistos como uma plataforma com poder socialmente transformador e democratizante (Herring et al., 2004). Estas plataformas disponibilizam informações com formato e conteúdo distinto, e oferecem aos leitores uma experiência democrática que não pode ser oferecida pela mídia tradicional. Os blogs apresentam uma série de características que os diferenciam das páginas pessoais em geral. Além da sua facilidade de utilização, a interatividade e a intertextualidade são também componentes essenciais à popularidade do mecanismo. A intertextualidade é o cruzamento de dados através das hiperligações, característica que confere alguma credibilidade aos bloggers e aos seus espaços de discussão (Araújo, 2011).

Atualmente, o principal segmento dos blogs são os relacionados a moda, que são usados como uma nova forma de compartilhar informação (Halvorsen et al., 2013). As mulheres gostam de descobrir as últimas tendências de beleza por meio de conteúdos e confiam em sites de beleza e blogs para ajudá-las a identificar o que está em alta no mercado de cuidados com o cabelo e pele, e cosméticos.

No estudo de beleza realizado pela Popsugar Insights, em 2014, constatou-se que $86 \%$ das mulheres procuram as últimas tendências em relação à área de beleza em blogs e websites, enquanto $54 \%$ recorrem às fontes 
tradicionais, como TV, revistas ou jornais. Em terceiro lugar com $38 \%$, estão as recomendações de amigos e familiares. A Figura 9 ilustra as fontes onde as consumidoras procuram conhecer novas tendências de beleza.

Figura 9 - Onde mulheres procuram de tendências de beleza

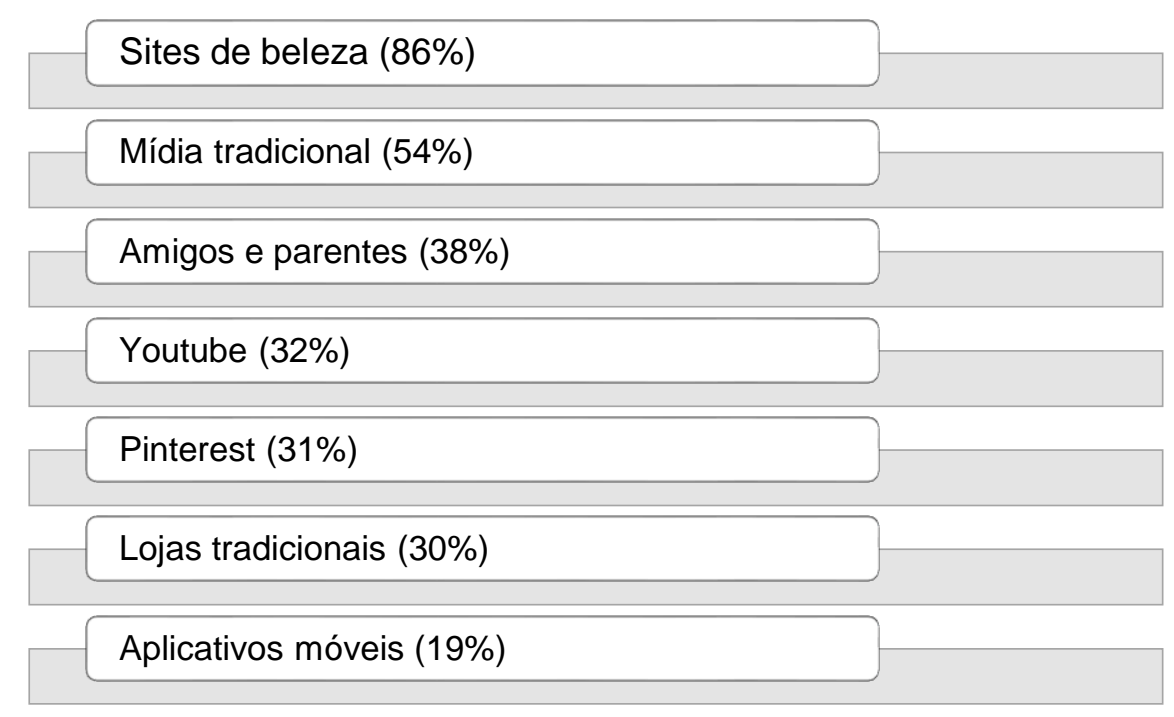

Fonte: Adaptado de Popsugar Insights, 2014.

Por sua vez, no que diz respeito ao conteúdo digital considerado mais inspirador, verificou-se que $54 \%$ consideram os sites e blogs de beleza como a maior fonte de inspiração como demonstra a Figura 10.

Figura 10 - Onde as mulheres se inspiram

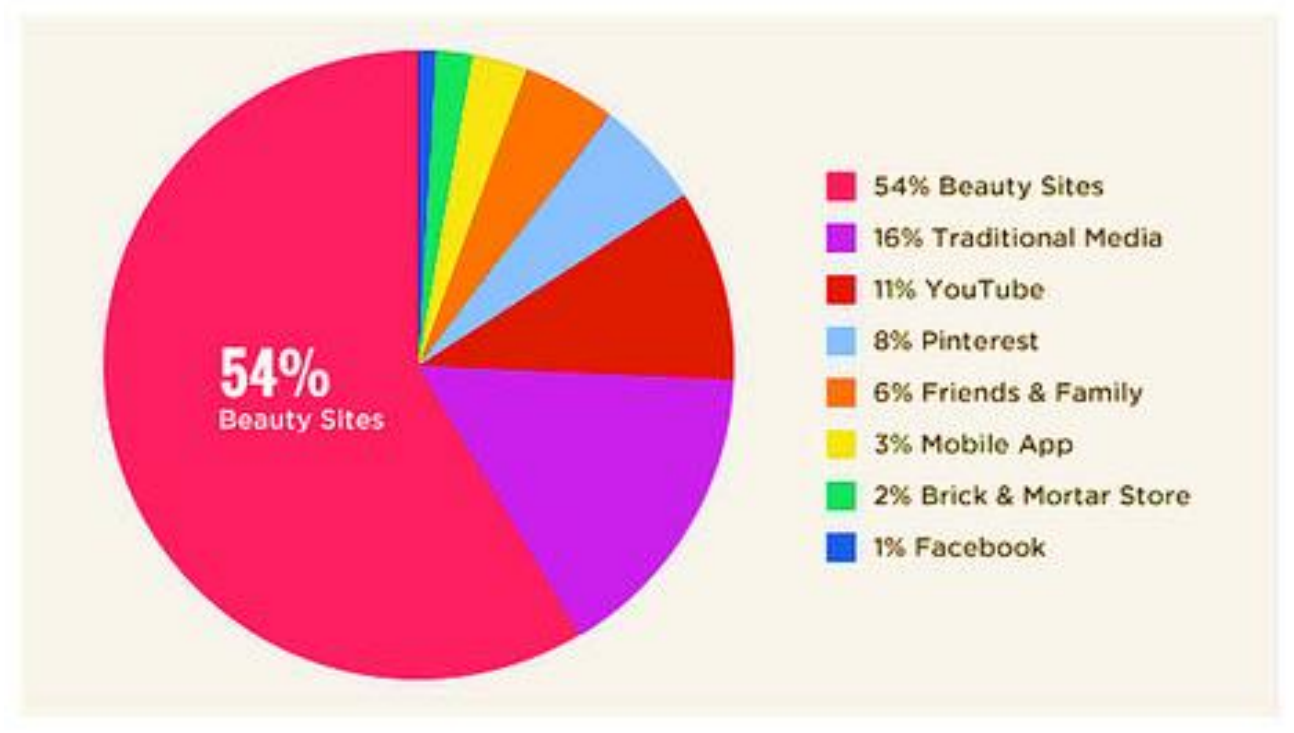

Fonte: Popsugar Insights, 2014. 
Existem várias maneiras de consumir conteúdo relacionado à beleza. Desde textos à imagens e vídeos, as mulheres podem facilmente descobrir conteúdo digital que as ajuda a identificar as tendências de beleza, aprender truques, e descobrir quais os produtos que são mais indicados para elas (McLoughlin, 2014). No mesmo estudo, foi constatado que a maioria das mulheres (73\%) consideram as resenhas de produtos como a fonte de conteúdo digital mais valiosa, seguido pelas dicas em geral com $62 \%$.

Figura 11: Conteúdo considerado mais valioso

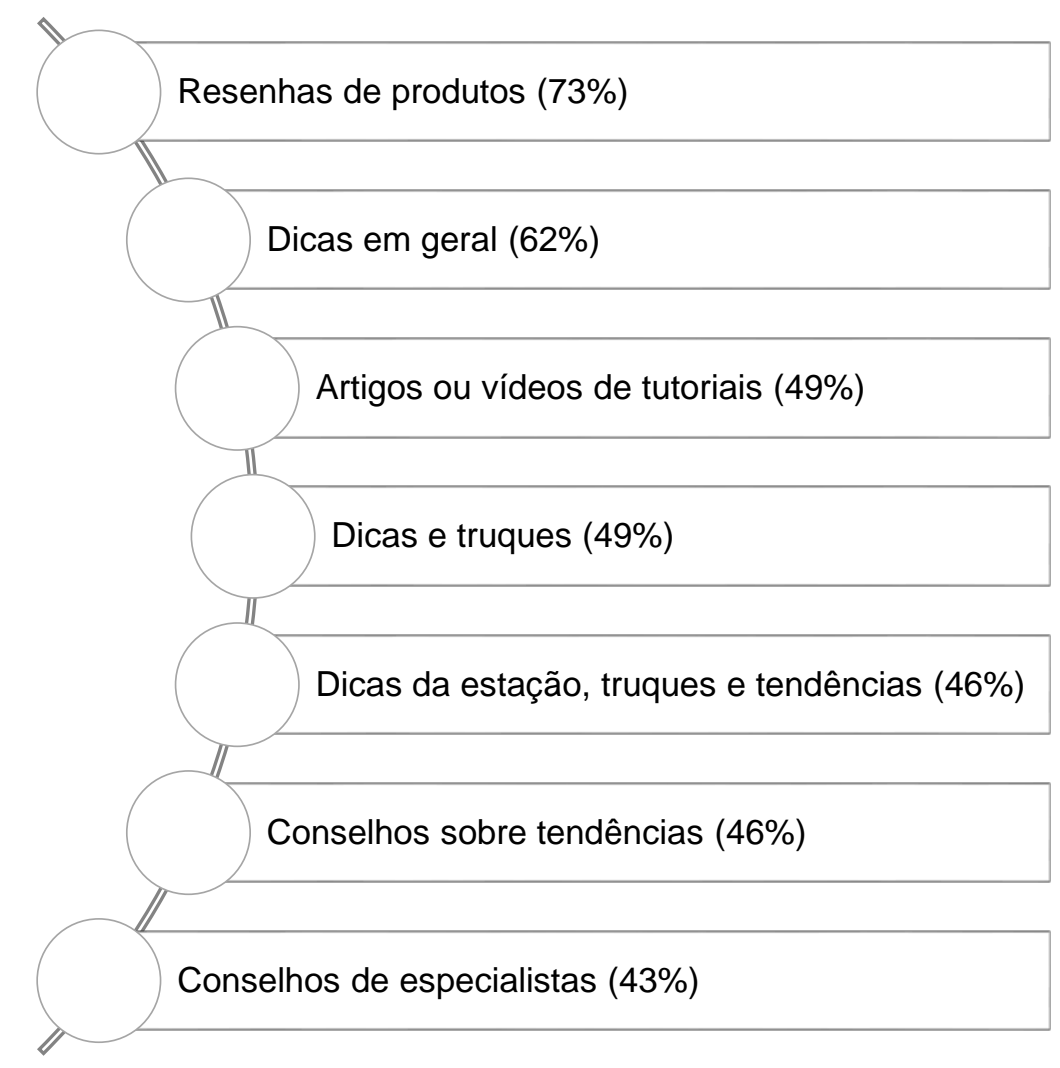

Fonte: Adaptado de Popsugar Insights, 2014.

Por fim, em relação aos fatores de maior influência na compra de produtos de beleza, $76 \%$ das mulheres afirmam que a marca é o quesito que tem maior influência na decisão de compra.

Recomendações de especialistas e artigos de blogs também têm um alto grau influência. 
Figura 12 - Principais fatores de influência na decisão de compra

\begin{tabular}{|c|c|}
\hline \multirow{4}{*}{$\begin{array}{l}\text { Drincipais } \\
\text { fatores de } \\
\text { influência na }\end{array}$} & Marca preferida $(76 \%)$ \\
\hline & Amostras grátis (65\%) \\
\hline & Recomendações de especialistas (62\%) \\
\hline & Editoriais/artigos lidos em blogs (52\%) \\
\hline decisão de & Preço (49\%) \\
\hline \multirow{6}{*}{ compra } & Recomendações de amigos e parentes (44\%) \\
\hline & Publicidades em revistas (26\%) \\
\hline & Vídeo assistido no youtube (26\%) \\
\hline & Artigo descoberto via mídia social (23\%) \\
\hline & Vídeo assistido em blog/site (22\%) \\
\hline & Publicidade em TV (12\%) \\
\hline
\end{tabular}

Fonte: Adaptado de Popsugar Insights, 2014.

Portanto, é possível apurar que os blogs contribuem para um novo formato de comunicação, socialização virtual e de compartilhamento de informação, relevando-se, assim, um ambiente em rede dinâmico de grande relevância.

\subsubsection{Conteúdos}

Os conteúdos dos blogs relacionados a moda e beleza podem ser bem diversificados e envolvem assuntos ligados à estilo, cuidados com pele e cabelo, celebridades e dicas de uso de produtos. Os conteúdos podem ser exibidos por meio de imagens, vídeos, textos, entre outros, e costumam estar divididos por temas nos blogs, sendo possível encontrar a informação desejada utilizando palavras-chave na ferramenta de busca existente nos sites.

A Alexa Internet - empresa de serviço de Internet pertencente à Amazon divulgou um ranking dos dez blogs de moda e beleza mais acessados em 2015 no Brasil conforme mostra a Figura 13. 
Figura 13 - Ranking de blogs de moda e beleza mais acessados no Brasil

\begin{tabular}{|c|c|}
\hline TDD 10 & $\begin{array}{r}1^{\circ} \text { Pausa para Feminices } \\
\text { Blogger: Bruna Tavares }\end{array}$ \\
\hline Blods de & $\begin{array}{l}2^{\circ} \text { Juro Valendo } \\
\text { Blogger: Jú Lopes }\end{array}$ \\
\hline Mdda $\mathrm{R}$ & $\begin{array}{l}3^{\circ} \text { Just Lia } \\
\quad \text { Blogger: Lia Camargo }\end{array}$ \\
\hline Beleza & $\begin{array}{l}4^{\circ} \text { Coisas de Diva } \\
\text { Blogger: Sabrina, Marina e Thais }\end{array}$ \\
\hline 2015 & $\begin{array}{l}5^{\circ} \text { Chata de Galocha } \\
\text { Blogger: Lú Ferreira }\end{array}$ \\
\hline & $\begin{array}{l}6^{\circ} \text { Blogueira S.A. } \\
\text { Blogger: Simone Aline }\end{array}$ \\
\hline & $\begin{array}{r}7^{\circ} \text { Depois dos Quinze } \\
\text { Blogger: Bruna Vieira }\end{array}$ \\
\hline & $\begin{array}{l}8^{\circ} \text { Camila Coelho } \\
\text { Blogger: Camila Coelho }\end{array}$ \\
\hline & $\begin{array}{l}9^{\circ} \text { Petiscos } \\
\text { Blogger: Julia Petit }\end{array}$ \\
\hline & $\begin{array}{l}10^{\circ} \text { Garotas Estúpidas } \\
\text { Blogger: Camila Coutinho }\end{array}$ \\
\hline
\end{tabular}

Fonte: Adaptado de Alexa, 2016.

Tendo como base os blogs que ocupam as três primeiras posições do ranking - Pausa para Feminices, Juro Valendo e Just Lia, ilustrados na Figura 14 - os tipos de conteúdos presentes nos blogs femininos voltado ao tema de moda e beleza são variados e as publicação abrangem desde reviews de produtos de beleza e maquiagem até rotinas diárias, tutoriais, entre outros.

Figura 14 - Blogs - Top 3

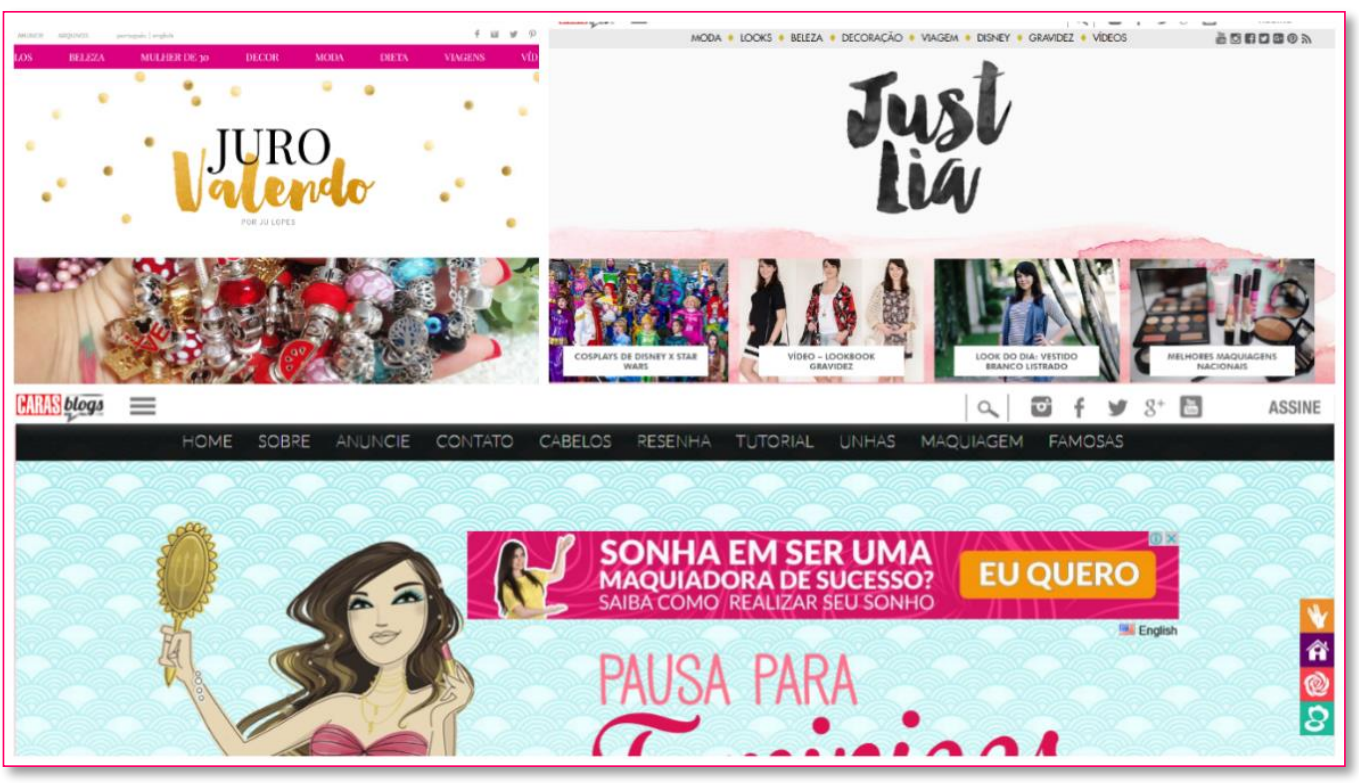

Fonte: Print screen dos blogs Juro Valendo, Just Lia e Pausa para Feminices. 
Na página inicial do blog da Bruna Tavares, Pausa para Feminices, os temas são divididos em: cabelos, resenha, tutorial, unhas, maquiagem e famosas. $\mathrm{Na}$ área de cabelos a visitante pode ver dicas de tratamento e cuidados, bem como dicas relacionadas ao uso de produtos. Na parte de resenhas, a blogueira relata sua experiência com o produto em questão. Os tutoriais ensinam truques de maquiagem e indicam como usar um determinado produto. Além disso, na publicação a blogueira lista os produtos usados no tutorial com os links de sites onde é possível adquiri-los. As publicações no setor Famosas apresentam os estilos de maquiagens usados por famosas e indica produtos similares.

Figura 15 - Pausa Para Feminices

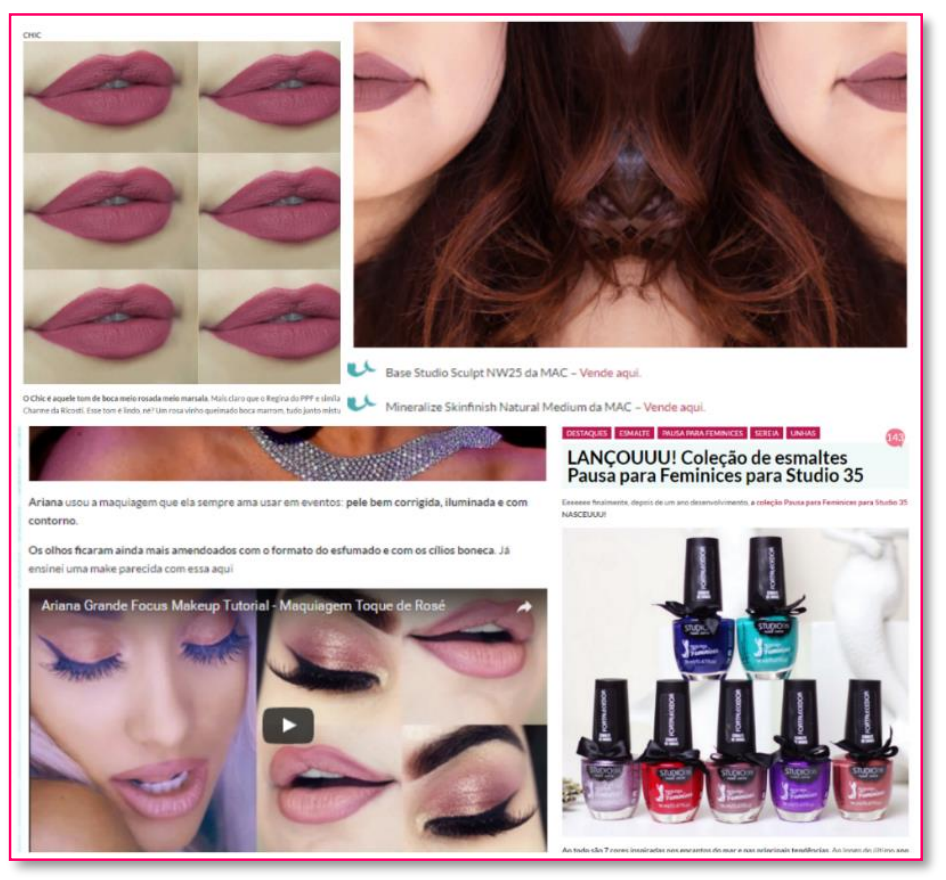

Fonte: Print screen do blog Pausa para Feminices.

Já o blog Juro Valendo da Jú Lopes, divide os temas em: cabelo, beleza, decoração, moda, saúde e viagens. O setor do site dedicado ao tema cabelo apresenta resenhas de produtos testados pela blogueira, dicas e lançamentos. $\mathrm{Na}$ parte de beleza, além de resenhas de produtos de maquiagem, há também publicações com participações das seguidoras, como o "TOP 10 da Leitora", onde as leitoras listam seus produtos favoritos. No setor relacionado à moda, as visitantes acompanham o look do dia da blogueira, assim como dicas de tendências e indicações de onde comprar os produtos. 
Figura 16: Juro Valendo

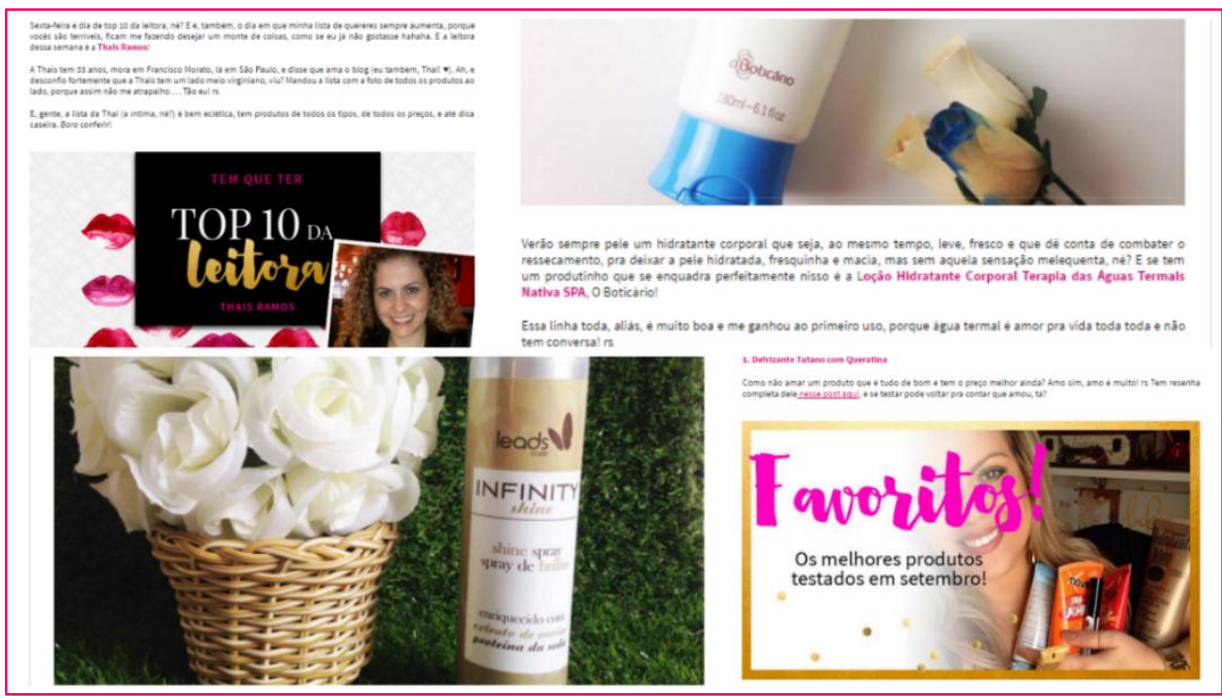

Fonte: Print screen do blog Juro Valendo

Por sua vez, no blog Just lia os temas são separados em: estilo, beleza, decoração, vídeo e look do dia. Em estilo, a blogueira Lia Camargo destaca as tendências de moda, publica dicas de como usar diversas peças de vestuário e apresenta o estilo de outras blogueiras. Na parte de maquiagem, também há resenhas de produtos e tendências do mercado.

Além disso, na barra lateral da página, há uma área dedicada a "itens desejo". Essa área divulga sugestões de produtos que estão linkadas a sites de e-commerce onde é possível adquiri-los.

Figura 17: Just Lia

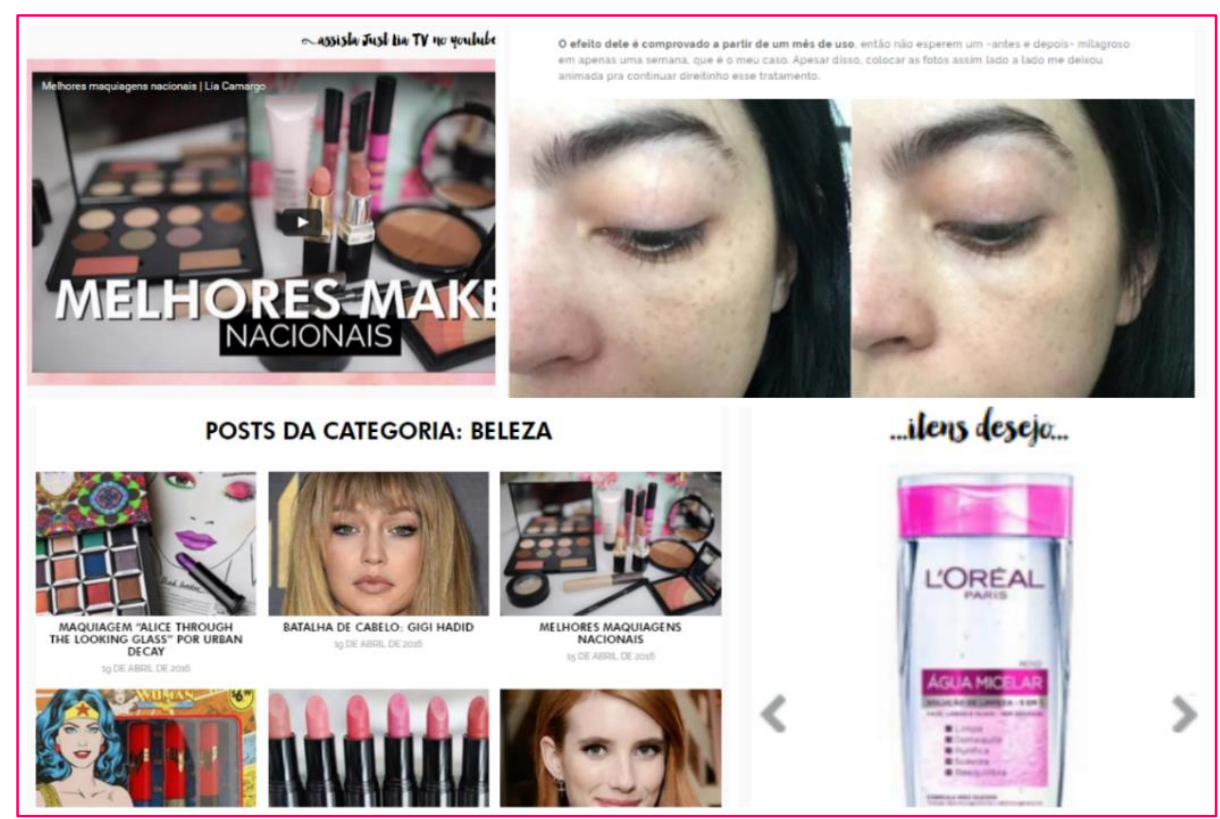

Fonte: Print screen do blog Just Lia 
Os blogs são uma forma de interação online e social onde ocorre o compartilhamento de informações e opiniões sobre diversos assuntos. A plataforma permite que os leitores interajam por meio de comentários, onde podem expor sua opinião, ou dar informações adicionais, a respeito do conteúdo publicado. Os tipos de conteúdo produzidos pelas blogueiras permitem que os consumidores consultem diversos tipos de informação que podem ajudar na escolha de um produto. As opiniões e experiências pessoais das blogueiras acerca de um produto podem ser negativas ou positivas. 


\section{Metodologia}

Este capítulo pretende informar sobre as diversas decisões acerca da forma como este estudo foi realizado.

\subsection{Tipo de pesquisa}

Segundo Gil (2002), em relação às pesquisas, é comum a classificação com base em seus objetivos gerais. Dessa forma, é possível classificar as pesquisas em três grupos: exploratórias, descritivas e explicativas.

A presente pesquisa será de caráter exploratório, e terá como objetivo conhecer os processos de formação de atitudes do consumidor e avaliar a intenção de compra a partir do uso de elementos visuais das embalagens de produtos alimentícios.

Conforme Gil (2002, p.41) explica:

Estas pesquisas têm como objetivo proporcionar maior familiaridade com o problema, com vistas a torná-lo mais explícito ou a constituir hipóteses. Pode-se dizer que estas pesquisas têm como objetivo principal o aprimoramento de ideias ou a descoberta de intuições. Seu planejamento é, portanto, bastante flexível, de modo que possibilite a consideração dos mais variados aspectos relativos ao fato estudado.

O tipo de pesquisa foi escolhido devido à sua maior flexibilidade e por ser útil para diagnosticar situações, explorar alternativas ou descobrir novas ideias.

\subsection{Seleção dos sujeitos}

O universo da pesquisa de campo é representado por consumidoras de produtos de beleza. Ainda que tenha havido um aumento de indivíduos do sexo masculino que se interessam pela temática, no contexto brasileiro ainda não é uma tendência fortemente estabelecida.

Outro fator importante a ser considerado é que as entrevistadas acessem blogs relacionados a moda, estilo e beleza. Assim, foram estabelecidos contatos com consumidoras que têm o hábito de consumir produtos de beleza e que acessem os blogs, pelo menos, uma vez ao mês. A maioria das entrevistadas contatadas eram conhecidas da pesquisadora e algumas foram indicadas por 
conhecida por se enquadrarem no perfil desejado. As respondentes são pertencentes às classes média e alta, residentes nas Zonas Norte, Sul e Oeste da cidade do Rio de Janeiro.

O estudo aborda, especificamente, as seguintes subcategorias de produtos de beleza: maquiagem, produtos de cuidados para cabelo, pele, rosto, mãos e unhas.

\subsection{Coleta de dados}

Os dados utilizados neste trabalho foram coletados por meio de pesquisa bibliográfica e pesquisa de campo (Gil, 2012). Isto é, as informações necessárias para o desenvolvimento deste trabalho foram obtidas por meio da coleta de dados primários e secundários.

Para recolher os dados secundários foi realizada uma pesquisa bibliográfica utilizando livros, artigos, revistas e a internet. Nesta etapa do trabalho de pesquisa que trata da coleta de dados primários, a ferramenta utilizada para dar resposta às questões de investigação identificadas foi a entrevista individual em profundidade.

Por permitir uma maior flexibilidade na exploração das questões, foi usado nas entrevistas um roteiro semiestruturado. Algumas vezes, foi necessário adaptar o roteiro da entrevista, pulando algumas perguntas quando já respondidas ou não aplicáveis, ou mesmo incorporando outras perguntas apropriadas.

O roteiro semiestruturado (ANEXO 1) foi dividido em três blocos:

- Bloco 1 - Perfil;

- Bloco 2 - Processo de decisão de compra;

- Bloco 3 - Influência dos blogs de moda e beleza.

Os blocos agruparam questões relacionadas ao perfil da respondente, ao processo de decisão de compra, a influência dos blogs relacionados a moda, estilo e beleza nas suas decisões de compra. As entrevistas foram gravadas de acordo com a autorização da entrevistada, e posteriormente foram transcritas para uma maior facilidade na análise dos dados. Nomes fictícios preservaram o anonimato das informantes.

$\mathrm{Na}$ investigação, o uso da entrevista teve como objetivo investigar a percepção das mulheres acerca do fenômeno dos blogs relacionados a moda, beleza e estilo, a compreender como estes blogs são usados como ferramenta 
de pesquisa, além de estudar a sua influência nas decisões de compra de produtos de beleza.

No total foram realizadas 15 entrevistas semiestruturadas. A coleta dos dados primários decorreu entre o dia 30 de abril de 2016 e o dia 18 de maio de 2016.

\subsection{Tratamento dos dados}

Os métodos para coleta e tratamento de dados são classificados como qualitativos e/ou quantitativos. Considerando-se a complexidade e a subjetividade das questões levantadas, foi utilizado o tratamento qualitativo, em que a coleta e análise dos dados não são baseadas na quantificação; elas analisam e descrevem o fenômeno em sua forma complexa.

Vieira e Zouain (2006, p. 15) definem o método qualitativo como o que "atribui importância fundamental à descrição detalhada dos fenômenos e dos elementos que o envolvem, aos depoimentos dos atores sociais envolvidos, aos discursos, aos significados e aos contextos".

Segundo Richardson (1999), há situações que implicam estudos de caráter qualitativo. Um exemplo são situações em que se evidencia a importância de uma abordagem qualitativa a fim de compreender aspectos psicológicos cujos dados não podem ser coletados de modo eficiente por outros métodos devido à complexidade que encerra. Nesse sentido, há estudos direcionados à análise de atitudes, motivações, expectativas, valores etc.

Antes de se iniciar a análise dos dados obtidos é importante organizá-los. Neste estudo, tal como já mencionado, os dados foram recolhidos por meio de entrevistas com roteiro semiestruturado e as respostas foram gravadas e, posteriormente, transcritas de forma a facilitar a análise. Após o registro e preparação dos resultados, deu-se início à análise e comparação dos mesmos.

\subsection{Limitação do método}

A limitação do método é inerente a qualquer pesquisa. Este estudo apresenta algumas limitações a serem consideradas, entre elas está a subjetividade da análise das entrevistas, uma vez que a mesma se baseará em percepções e interpretações da pesquisadora, havendo assim limitação quanto à exatidão das informações. 
Outra limitação está relacionada à abrangência da pesquisa de campo. Mesmo que o método utilizado não busque a generalização, os resultados não podem ser explorados para todo o universo de consumidores de produtos de beleza. Dessa forma, a função deste trabalho é levantar hipóteses. 


\section{Apresentação e análise dos resultados}

Este capítulo, tem como objetivo apresentar e discutir os resultados obtidos, bem como analisar e discutir suas implicações. Esta análise partiu essencialmente das questões de investigação previamente estabelecidas, considerando ao mesmo tempo as evidências da literatura.

Inicialmente, serão apresentados os resultados do estudo exploratório, e em seguida será apresentada a análise dos resultados. Os resultados serão comentados tendo-se como base a revisão de literatura efetuada.

\subsection{Descrição e análise dos resultados}

Nesta seção serão apresentados os resultados da abordagem qualitativa, recorrendo à transcrição e análise de frases ditas durante as entrevistas. A fim de facilitar a compreensão dos resultados obtidos, serão apresentados em quadros-síntese, quando aplicáveis, os diferentes tipos de resposta.

Este tópico encontra-se estruturado em quatro temas: caraterização do perfil sócio demográfico do conjunto de entrevistadas; hábitos de compra e uso de produtos de beleza; processo de decisão de compra e influência dos blogs relacionados a moda, estilo e beleza na intenção de compra.

\subsubsection{Caracterização do perfil sócio demográfico das entrevistadas}

Foram realizadas 15 entrevistas com mulheres, em que se buscava informantes com idades entre 18 e 35 anos que acessassem blog relacionados a moda, estilo e beleza ao menos uma vez por mês. Ao analisar o Quadro 1, referente ao perfil das entrevistadas, é possível verificar que a idade das mesmas varia entre os 21 e os 35 anos, obtendo-se uma média de 26,6 anos.

Tendo em conta os dados referentes à pesquisa da Nielsen IBOPE (2014), apresentado no Capítulo 2, este fator era esperável, visto que o grupo com maior acesso à internet está na faixa etária de 25 a 34 anos. 
Quadro 1: Perfil das entrevistadas

\begin{tabular}{|c|c|c|c|c|}
\hline Nome & Idade & Residência & Grau de instrução & Profissão \\
\hline Bianca & 22 & Madureira & Pós-graduação & Enfermeira \\
\hline Camila & 27 & Ipanema & Pós-graduação & Arquiteta \\
\hline Camilla & 26 & Vila Isabel & Ensino Superior & Engenheira \\
\hline Cinthya & 28 & Flamengo & Superior & $\begin{array}{l}\text { Gerente } \\
\text { Bancária }\end{array}$ \\
\hline Débora & 23 & Tijuca & Superior & $\begin{array}{l}\text { Estagiária } \\
\text { de Direito }\end{array}$ \\
\hline Denise & 33 & Tijuca & Pós-graduação & $\begin{array}{l}\text { Servidora } \\
\text { pública }\end{array}$ \\
\hline Giulia & 25 & Barra & Superior & $\begin{array}{l}\text { Designer } \\
\text { Gráfico }\end{array}$ \\
\hline Karina & 28 & Recreio & Superior & Arquiteta \\
\hline Larissa & 26 & Vila Isabel & Superior & $\begin{array}{l}\text { Trainee em } \\
\text { Consultoria }\end{array}$ \\
\hline Manoela & 27 & Tijuca & Superior & Advogada \\
\hline Miria & 35 & Grajaú & Ensino médio & Vendedora \\
\hline Patricia & 21 & Centro & $\begin{array}{l}\text { Superior } \\
\text { Incompleto }\end{array}$ & $\begin{array}{l}\text { Estagiária } \\
\text { de } \\
\text { Jornalismo }\end{array}$ \\
\hline Rafaela & 25 & Botafogo & Superior & Advogada \\
\hline Raquel & 25 & Tijuca & Pós-graduação & Psicóloga \\
\hline Rebeca & 28 & Barra & Superior & $\begin{array}{l}\text { Assistente } \\
\text { Comércio } \\
\text { Exterior }\end{array}$ \\
\hline
\end{tabular}

Fonte: Autora

Verifica-se que a maioria das consumidoras entrevistadas frequentaram o Ensino Superior. Observa-se também que nenhuma entrevistada se encontrava em situação de desemprego, ou seja, todas tinham renda no momento das entrevistas.

\subsubsection{Hábitos de compra e uso de produtos de beleza}

O roteiro das entrevistas buscou caracterizar os hábitos das entrevistadas em relação aos tipos de produtos de beleza que mais compram e os que mais utilizam, bem como a presença desses produtos na sua rotina.

Todas as entrevistadas afirmaram utilizar mais de um tipo de produto de beleza diariamente. As categorias de produto mais citadas foram os produtos de cuidados para rosto/pele, esmalte e maquiagem. A maioria afirma que os 
produtos que compra mais frequentemente são os utilizados no dia a dia, como hidratantes, produtos para os cabelos, esmaltes, etc. A maquiagem mais pesada é usada em ocasiões especiais.

A maioria é praticamente de uso diário. A não ser a maquiagem que depende da ocasião. No dia a dia dou preferência à maquiagem mais leve, um corretivo, gloss (Manoela).

Compro sempre produtos para a pele, creme para o corpo e cabelos, e a frequência da compra desses é contínua, por se tratar de itens essenciais de cuidados e higiene pessoal (Miria).

Outro hábito mencionado é o fato de preferir comprar os produtos mais caros quando viajam, como relataram as entrevistadas Giulia e Raquel.

Gosto de manter produtos mais baratos para o dia a dia já que pelo uso diário, compro com mais frequência. Enquanto as maquiagens para sair à noite, festas, são mais caras, muitas delas compradas quando viajo para o exterior (Giulia).

Compro muita coisa quando eu viajo ou minha mãe viaja, produtos importados. Aqui o que mais compro é a base com protetor, e o sabonete líquido para o rosto, para o meu tipo de pele (Raquel).

Quando questionadas se têm algum produto de beleza que compraram ou não usam, a maioria respondeu que sim. O principal motivo apontado foi terem comprado o produto e este não ter correspondido às expectativas e/ou não terem se adaptado a ele, como podemos ver por meio do depoimento da entrevistada Rafaela "Possuo produtos que comprei e não consegui utilizar, muito pela textura ou falta de resultado com os mesmos".

É interessante destacar que em alguns casos os blogs foram citados como influenciadores na aquisição do produto que não é utilizado, como podemos ver no depoimento da Camilla: "Às vezes compro para experimentar produtos que vi em blogs, mas não gosto ou não me adapto", ou no depoimento da Denise "Acredito que os blogs influenciam sim, com certeza, pois conteúdos vistos em blogs podem despertar o consumismo, pelo menos, atualmente, eu creio nisso". Já Rebeca argumentou acerca da influência positiva dos blogs na compra de produtos.

Sou um pouco influenciável pelo desejo na verdade. Os blogs me auxiliam a verificar se o produto que acho que devo comprar ficará ou não de acordo com o que eu quero através das resenhas de blogueiras. Se os blogs não existissem, com certeza eu teria mais produtos que não uso do que já tenho (Rebeca). 
Dentre as cinco entrevistadas que responderam não à pergunta sobre não usarem algo que comparam, Raquel e Larissa disseram que tiveram produtos que não usavam por mudança de hábito, e deixaram de comprar. Além disso, foi mencionada por outras entrevistadas a importância de comprar apenas o que precisa a fim de evitar produtos encalhados no armário.

É meio difícil, porque antes de comprar eu faço uma lista do que preciso. O que vai suprir minha necessidade. Eu não compro nada além do que eu vou usar. Se eu compro alguma coisa que acabo não usando, eu acabo dando para alguém (Patricia).

Não costumo comprar algo só por comprar. Geralmente compro o que estou precisando no momento (Manoela).

\subsubsection{Processo de decisão de compra}

Inicialmente, procurou-se compreender um pouco mais acerca do processo de decisão de compra das entrevistadas. Foram feitas perguntas para saber 0 que levam em conta ao escolher um produto de beleza, onde buscam informações e com quem as compartilham, e se a opinião de terceiros é importante nesse processo.

De acordo com a pesquisa realizada pela empresa Sophia Mind (2009) que teve como um dos objetivos entender como ocorre o consumo de produtos e tratamentos de beleza, a qualidade é um dos atributos mais importantes na decisão de compra, bem como a indicação de um profissional de confiança.

A Figura 18 indica os fatores que mais influenciam as entrevistadas na escolha de um produto de beleza. As palavras com tamanho maior de fonte foram as mais citadas pelas entrevistadas, sendo assim, o atributo mais citado foi a qualidade do produto, seguido da marca.

Figura 18 - Principais atributos que influenciam na escolha do produto

Fonte: Autora

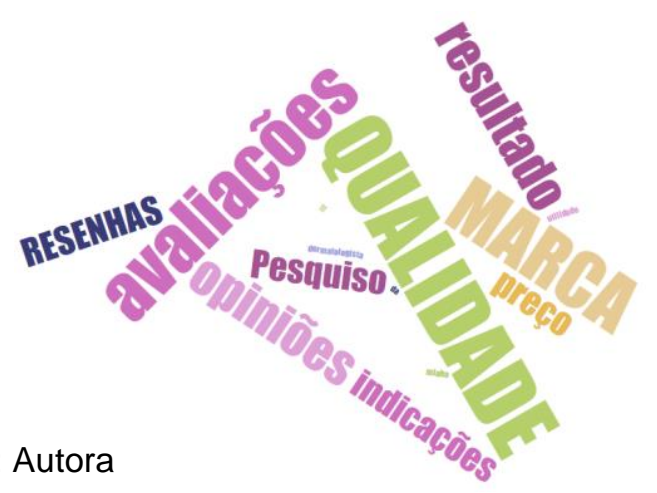

Vale ressaltar que a marca, quando mencionada, está atrelada à percepção da qualidade do produto por parte das entrevistadas. As avaliações, 
indicações e opiniões de amigas, blogueiras e dermatologistas também foram mencionadas pela maioria das respondentes. A pesquisa de resenhas e avaliações o resultado prometido/esperado também é de grande importância e para a maioria os dois fatores estão relacionados, pois a pesquisa é considerada uma boa ferramenta para avaliar se vale a pena comprar o produto ou não. Já o preço é o atributo menos mencionado.

\subsubsection{Pesquisa de informação na fase pré-compra}

Segundo Engel, Blackwell e Miniard (2000), a principal motivação da busca pré-compra é o desejo de fazer melhores escolhas ao comprar um produto. Partindo do modelo de processo de decisão proposto por Hawkins, Best e Coney (1998), a busca de informação é etapa na qual o indivíduo identifica alternativas, considera os benefícios e riscos. A pessoa pode procurar informações relevantes de fontes internas e/ou externas a fim de chegar a um conjunto de alternativas para o problema ou necessidade e de reduzir o risco na tomada de decisão.

$\mathrm{Na}$ presente pesquisa tentou-se perceber se as entrevistadas têm por hábito pesquisar informação na etapa pré-compra. Além disso, verificou-se onde essa informação é pesquisada e os motivos para que isso aconteça. Todas as entrevistadas afirmaram pesquisar informações antes de comprar algum produto de beleza. Em seguida, tentou-se perceber ainda a que meios recorrem para a obtenção dessa informação. O Quadro 2 apresenta uma síntese dos meios pelos quais as entrevistadas buscam as informações antes da compra.

Quadro 2: Plataformas de pesquisa

\begin{tabular}{|l|}
\hline Plataforma \\
\hline Blogs \\
Instagram + Blogs \\
Blogs + Opiniões de amigas \\
Google + Blogs (direcionado) \\
Youtube \\
Internet no geral \\
Loja e blog \\
\hline
\end{tabular}

Fonte: Autora

Por meio dos dados obtidos consegue-se perceber que a pesquisa da informação na fase pré-compra das entrevistadas ocorre, para a maioria, no 
ambiente online, seguido de opiniões de amigas. Os dados estão de acordo com o estudo de beleza realizado pela Popsugar Insights, em 2014, que constatou que a maioria das mulheres procuram as últimas tendências em relação à área de beleza em blogs e websites, enquanto uma parcela menor recorre às fontes tradicionais, como TV, revistas ou jornais. Outras fontes de informação apontada na pesquisa foram as recomendações de amigos e familiares.

A literatura destaca a importância os aspectos mais importantes que o uso da internet proporcionar aos consumidores, uma vez que lhes permite o acesso à uma grande quantidade e disponibilidade de informação (Wolfinbarger e Gilly, 2001). Dessa forma, os consumidores podem reduzir o risco na sua tomada de decisão.

O uso do Google foi citado como uma ferramenta de busca para serem direcionadas a algum conteúdo de blogs, como contou Giulia: "Quando penso em comprar um produto que não conheço ainda, dou um google "produto $\mathrm{x}+$ resenha/swatch" e leio uns cinco posts diferentes". Já o Youtube é usado para saber modo de usar o produto.

É também interessante comentar acerca da preferência de Camila e Karina, que costumam ir às lojas depois de ler acerca de um produto em algum blog.

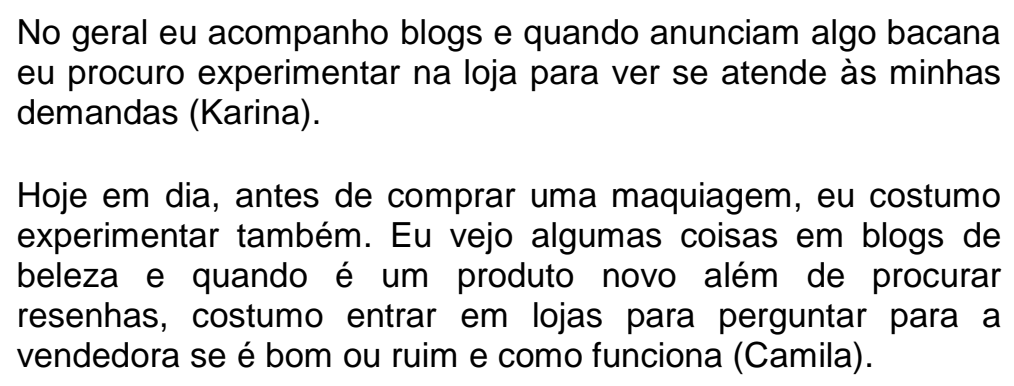

As motivações das participantes para realizarem a pesquisa de informação pré-compra e para a escolha da plataforma utilizada também é um ponto relevante. De acordo com os depoimentos das entrevistadas identificou-se as principais motivações: obter opiniões reais acerca dos produtos; saber se o produto é adequado e se vale a pena comprar e ver explicações de como usar.

O depoimento da Larissa e Camilla, respectivamente, mostram que a motivação para a pesquisa está relacionada com obter a opinião real de alguém que já usou o produto, "Sim, para saber se realmente é confiável pergunto a opinião de amigas que já usaram ou vejo em blogs. Às vezes o produto é caro e nem vale a pena" (Larissa), "Costumo pesquisar para ter uma opinião de quem já usou o produto e assim saber se ele é bom e se vale a pena. Pesquiso mais em blogs e perguntando para as minhas amigas" (Camila). 
Após obter informação mais detalhada e opiniões acerca dos produtos, as entrevistadas conseguem avaliar se o resultado dos mesmos é bom e também saber como funcionam como contou Miria: "Procuro informação para garantir que o resultado do produto é bom". Já Rafaela relatou seu hábito de pesquisar informações sobre o produto antes de comprá-lo:

Quando pretendo comprar algum novo produto eu costumo
fazer uma pesquisa sobre o mesmo pela internet, em blogs,
neles posso encontrar as opiniões diferentes pessoas e assim
formar uma ideia mais concreta do resultado esperado e de
como funciona determinado produto, que por muitas vezes
difere do que está escrito no rótulo assim como nas suas
propagandas (Rafaela).

Dessa forma, também evitam ficar limitadas às informações dadas pelas marcas nos rótulos e/ou propagandas.

Os depoimentos mostram que as entrevistadas tendem a confiar mais na informação oriunda da opinião e experiência de outros consumidores do que da informação disponibilizada pelas marcas. Tanto o boca-a-boca e boca-a-boca eletrônico, isto é, o compartilhamento de informação e experiências sobre produtos entre consumidores, exercem influência na escolha do consumidor.

\subsubsection{Influência de terceiros no processo de compra}

Conforme a literatura, os fatores sociais têm uma grande influência no processo de decisão de compra dos consumidores. Para Churchill e Peter (2003) cada pessoa é influenciada por vários grupos, dentre eles estão os grupos de referência, como família, amigos, colegas, profissionais com experiência na área, grupos aspiracionais e líderes de opinião. Logo, a influência de terceiros foi um tema a ser abordado neste trabalho.

De todas as entrevistadas, dez afirmaram que a opinião de terceiros é importante nas suas decisões de compra de produtos de beleza. Quatro consideram a opinião de terceiros importante levando em conta a experiência ou conhecimento do indivíduo em relação ao produto. Apenas uma entrevistada afirmou que por ser impulsiva não considera relevante a opinião de outros.

Alguns dos depoimentos exemplificam os tipos de influências sociais que podem afetar as decisões de compra das entrevistadas, como amigas, familiares, outros consumidores ou profissionais da área. No entanto, para algumas entrevistadas a influência de terceiros depende da situação e do produto, como mostra o depoimento da Larissa: "É importante a opinião de alguém que já comprou, experimentou e usou durante um tempo. Por exemplo, 
se for produto para pele oleosa - que eu uso bastante - eu tenho que saber se realmente funciona". Também o de Débora "Depende. Se eu quero saber mais a respeito de um certo produto e sei de alguém que tenha experimentado já, eu acho que vale a pena perguntar sim. Ainda mais quando é algum produto para alergia, pele oleosa, nesses casos a opinião da medica é essencial". Bianca considera importante, mas a decisão final é dela: "Às vezes só...só quando fico em dúvidas de qual opção comprar. Mas na maioria das vezes, quem decide sou eu mesma".

Assim como defendem Park e Lessig (1977, apud Solomon, 2011, p. 409), há três formas de influência dos grupos de referência: informacional, utilitária e expressiva de valor. Em linha com os autores, as entrevistadas preferem ouvir as opiniões de pessoas que tenham informações confiáveis sobre o produto em questão, ou com pessoas que lidem profissionalmente com o produto, e também podem ser influenciadas pelas preferências das pessoas com quem interagem socialmente. Camilla aponta a importância das avaliações positivas das pessoas que já utilizaram o produto: "A opinião dos outros é importante para determinar a qualidade. Quando muitas pessoas que usaram dizem que é bom, eu confio mais do que quando ninguém nunca utilizou o produto".

A maioria das entrevistadas deu maior importância às opiniões de amigas nas suas decisões de compra, uma vez que tendem a confiar mais nessas pessoas. "Geralmente comento com minhas amigas sobre algum produto novo que eu ouvi falar, pergunto se alguém já usou, se gostou. Se uma delas falar que já usou e não gostou, eu provavelmente não vou comprar". (Giulia). "Sim, é importante. Eu acho que é sempre bom confirmar com alguém que usou os resultados dos produtos, a eficácia. Converso muito com as minhas amigas sobre isso, se eu estou procurando uma dica eu pergunto para elas se podem dar alguma" (Manoela).

Algumas entrevistadas mencionaram as opiniões e familiares como importantes. "É importante para mim a opinião dos meus familiares, amigos e blogs sobre determinado produto que pretendo comprar" (Rafaela). Ou, ainda, a opinião de especialistas conforme comentou Camila: "A indicação da minha dermatologista também importa bastante na minha decisão pois ela conhece meu tipo de pele".

De acordo com Miria, os outros consumidores têm influência nas suas decisões de compra: "A opinião de amigos e família não é importante, mas de outros consumidores sim, porque é sempre interessante entender, mesmo que não tenha dado certo, o que o produto traz de bom ou não, e por terem tido 
experiência com o produto, a opinião é mais confiável". Ou seja, a entrevistada prefere a opinião de outros consumidores por possuírem experiência direta com o produto e passarem mais confiança ao compartilharem informações acerca do produto.

Em síntese, a opinião de terceiros ajuda a tomar decisões porque a experiência, o conhecimento e a credibilidade dessas pessoas são fatores considerados importantes e levados em conta na hora da decisão de compra.

\subsubsection{Influência dos blogs relacionados a moda, estilo e beleza na intenção de compra}

Neste bloco, procurou-se entender um pouco mais a respeito da "febre" dos blogs de moda e beleza segundo as opiniões das entrevistadas, e a influência que podem exercem sobre as suas decisões de compra.

\subsubsection{Como descobriram os blogs e a frequência com que os acessam}

Procurou-se compreender como as entrevistadas descobriram esse tipo de blogs e a frequência com que os acessam. As entrevistadas identificaram algumas das fontes que as levaram a entrar no mundo dos blogs de moda, estilo e beleza, conforme mostra o Quadro 3 demonstra:

Quadro 3: Como descobriram os blogs

\section{Google}

Amigas ou conhecidas

Familiares

Outras redes sociais (Instagram, Facebook, Youtube)

Outras mídias (TV, revistas)

Fonte: Autora

Ao longo das entrevistas, a fonte mais mencionada foi o Google, tal como relatou Miria ao falar sobre como encontrou os blogs em questão: "Através da internet mesmo, pesquisando no Google“.

Outras entrevistadas mencionaram também que descobriram os blogs por meio dos comentários de amigas ou conhecidas e membros da família, como 
contou Karina "Descobri por meio de amigas", ou até por meio das próprias autoras, conforme respondeu Giulia "Fiz um curso de desenho de moda com as fundadoras do Fashionismo um pouco antes de lançarem o blog, então acabei descobrindo o universo dos blogs quando elas comentaram sobre isso. A partir do Fashionismo fui conhecendo outros".

As redes sociais, como Instagram, Facebook e Youtube, também foram citadas por algumas entrevistadas. "Geralmente vejo algo em alguma rede social que me direciona para alguma publicação" (Larissa), "Por outras redes sociais, como o Instagram... " (Bianca). É interessante notar que, ocasionalmente, a descoberta ocorre no ambiente online por meio de amigas de forma indireta, conforme relatou Débora: "Descobri pesquisando no Google ou por amigas de forma indireta, às vezes alguma amiga curte uma publicação no Facebook ou Instagram. Já pesquisei tutoriais no Youtube e descobri uma blogueira legal. Muitas têm mais de um canal de relacionamento que estão interligados entre si. Instagram, Youtube, Facebook, além do blog". Outras mídias como TV e revistas foram mencionadas apenas por uma entrevistada.

Em relação à frequência com que os acessam, um terço das entrevistadas acessa diariamente ou mais de uma vez por semana. O restante costuma acessar quinzenalmente ou pelo menos uma vez ao mês. Por meio dos depoimentos de algumas entrevistadas, observou-se um fator que motiva e aumenta a frequência de acesso é quando elas reconhecem a necessidade de comprar um produto e querem saber mais informações a respeito do mesmo, "Diria que acesso quinzenalmente ou quando preciso comprar algo e quero me informar a respeito" (Débora). "Uma vez por mês, ou quando estou precisando comprar algum produto e não sei qual escolher ainda" (Denise). Larissa, por exemplo, passa a acessar quase diariamente quando está em busca de um produto: "Agora não estou procurando nenhum produto, mas quando estou acesso praticamente todos os dias".

Por outro lado, um dos motivos apontados para o acesso menos frequente é a falta de tempo, conforme pode-se observar no depoimento da Débora: "Antigamente eu acessava bastante. Hoje em dia só tenho mais tempo disponível aos finais de semana”, e de Raquel: “... uma ou duas vezes por mês. Já acessei mais quando era mais nova. Hoje em dia falta tempo". 


\subsubsection{Aspectos positivos e negativos do conteúdo sob o ponto de vista das entrevistadas}

É interessante ver quais blogs as entrevistadas acessam e o tipo de conteúdo que mais gostam e os que menos gostam, bem como as razões para tal. Todas as entrevistadas costumam acessar mais de um blog diferente. Entre os blogs mais citados estão: Pausa para Feminices, Coisas de Diva, Fashionismo, Starving e Just Lia.

Como visto no estudo da Popsugar Insights (2014), existem várias maneiras de consumir conteúdo relacionado à beleza: desde textos até imagens e vídeos que ajudam a consumidora a identificar as tendências de beleza, aprender truques, e descobrir quais os produtos que são mais indicados para elas. No mesmo estudo, foi constatado que a maioria das mulheres pesquisadas considera as resenhas de produtos como a fonte de conteúdo digital mais valiosa, seguido pelas dicas em geral.

Do mesmo modo a literatura aponta que as resenhas têm bastante importância nas decisões de compra dos consumidores. Antigamente, a informação era compartilhada com outros consumidores apenas oralmente na forma da comunicação boca a boca, e as pessoas não tinham a oportunidade de divulgar suas opiniões com outros consumidores e formato escrito e estruturado. O objetivo das resenhas online de produtos é de informar aos consumidores em potencial acerca dos pontos fortes e fracos do produto em questão. Pessoas que compartilham suas experiências ajudam outros consumidores a tomarem decisões de compra e podem até ser vistos como especialistas no assunto se suas resenhas são consideradas de melhor qualidade (POLLACH, 2006).

Quando questionadas sobre o tipo de conteúdo que mais gostam, as resenhas e os vídeos foram os conteúdos mais citados. "Gosto das resenhas de produtos que me ajudam na hora de comprar algum cosmético" (Cinthya); "Gosto de ver a resenha de algum produto, quando tem vídeo de recebidos do mês que aparecem várias coisas" (Camila); "Eu acompanho mais o canal de vídeos, gosto muito de assistir. Me sinto mais próxima da pessoa e é mais dinâmico" (Patricia). Rebeca ainda destacou a importância dos vídeos nas publicações de resenha: “...acho que muito texto, dependendo do post, acaba se tornando desnecessário. Se for uma resenha não faz sentido não demonstrar bem o produto aplicado e/ou como foi aplicado através de vídeos ou fotos".

Além da importância dos aspectos visuais, outro aspecto bastante mencionado pelas entrevistadas é a estruturação das publicações. Para algumas 
delas, é importante que a informação seja apresentada de forma clara e objetiva. "Gosto da forma rápida e direta com que passam as informações, além das opiniões das blogueiras que testam os produtos e dão uma opinião honesta, as imagens e vídeos também são muito esclarecedores" (Karina); "Gosto mais quando são práticos, diretos, tem bons resumos e quando tem vídeos não muito longos. Não gosto quando as resenhas são gigantes" (Larissa).

Dentre os conteúdos menos preferidos entre as entrevistadas, o mais citado foi a seção de dicas do dia em moda e estilo das blogueiras, "O que menos gosto é parte do look do dia, ou a roupa que fulana usou em tal evento" (Débora); "Não gosto de blogs com look do dia, como Blog da Thássia, gosto dos blogs que citei porque neles leio sobre tendência, comportamento, dicas de produtos, viagens, livros, séries e não o que a blogueira $X$ vestiu na festa $Y$ " (Giulia), o que aponta uma preferência para a seção que aborda o tema de produtos de beleza ao vez das publicações focadas em moda, conforme relata a entrevistada Raquel: "Gosto dos temas de beleza, estilo de vida, coisas fitness. $E$ cuidados da pele também. $O$ mais útil são as dicas. $E$ o que eu menos me interesso é por moda, tipo tal roupa, tal sapato. Prefiro as dicas de beleza".

Em contrapartida, o conteúdo variado é visto como fator positivo quando o tema abordado é comportamento, entretenimento, viagens, saúde, como visto nos depoimentos de Raquel, Giulia, e no da Camilla: "Gosto das resenhas de produtos que me ajudam na hora de comprar algum cosmético, dicas em geral, moda, looks do dia, tendências, reflexões, viagens. Gosto do conteúdo variado".

Outro fator visto como negativo por várias entrevistadas é a presença em demasia de publicidade e propaganda, principalmente, quando a presença de material publicitário não está indicada na publicação como sendo espaço pago. "Não gosto quando as publicidades não têm muito a ver com o meu perfil e não gosto de ver os desfiles de moda. Acho muito fora da realidade" (Camilla); "O que menos gosto atualmente nos blogs em geral é a publicidade em demasia sem a devida indicação de publicidade" (Denise).

O Quadro 4 resume as opiniões das entrevistadas acerca dos tipos de conteúdo existentes nos blogs. 
Quadro 4: Opinião acerca dos tipos de conteúdo dos blogs

\begin{tabular}{|l|l|}
\hline \multicolumn{1}{|c|}{ O que mais gostam } & \multicolumn{1}{c|}{ O que menos gostam } \\
\hline Opinião honesta & Falar só dos aspectos positivos do produto \\
\hline Resenhas e dicas & Divulgar produtos inacessíveis e caros \\
\hline Vídeos de tutoriais & Quando não se identificam com o perfil do produto \\
\hline Tendências e dicas & Propaganda \\
\hline Publicações com textos diretos & Look/estilo do dia \\
\hline
\end{tabular}

Fonte: Autora

\subsubsection{Blogs relacionados a moda, estilo e beleza como plataformas de pesquisa de informação na fase pré-compra}

Ao serem questionadas se consultam ou já consultaram algum dos blogs citados por elas mesmas antes de realizar um compra, todas as entrevistadas afirmaram que sim. Sendo assim, é possível perceber que as ferramentas online, como blogs, assumem cada vez mais um papel importante na pesquisa de informação na fase de pré-compra por parte dos consumidores por oferecerem aos consumidores um autêntico canal de comunicação que é mais confiável que uma propaganda (Rassega et al., 2015).

Como foi relatado pela Camila, os blogs também têm como aspecto positivo a facilidade que proporcionam para se buscar a informação desejada "Hoje em dia é a forma mais fácil de você descobrir alguma coisa sobre um produto. Embora que só testando é que você sabe se é bom para você ou não".

O tipo de conteúdo mais buscado nesses blogs são as resenhas, opiniões e avaliações, "Consulto mais para ver as resenhas sobre o produto e saber a opinião de quem já utilizou" (Cynthia); "Geralmente procuro a opinião das blogueiras - e até das próprias leitoras que comentam -, sobre os produtos (...) É sempre bom saber o que uma pessoa que usou e testou tem a falar sobre o produto ou marca" (Denise). Algumas entrevistadas disseram que também têm o costume de pesquisar sobre um produto específico quando querem saber mais informações acerca dele e se é adequado para elas, “... já consultei principalmente para saber se funciona no meu tipo de pele e cabelo" (Manoela), ou se atingirão suas expectativas "Os blogs me auxiliam a verificar se o produto que acho que devo comprar ficará de acordo com o que planejo através das 
resenhas de blogueiras" (Rebeca), ou até para obter informações sobre produtos similares "Informação, saber se o produto é bom, se há algum similar que seja melhor" (Larissa). Os tutoriais também foram mencionados, como no relato da Raquel "Tutoriais também para aprender a fazer uma maquiagem legal".

O Quadro 5 resume os tipos de conteúdo mais procurados pelas entrevistadas ao acessar um blog relacionado à moda, estilo e beleza.

Quadro 5: Conteúdo procurado nos blogs

\begin{tabular}{|l|}
\hline Conteúdo procurado \\
\hline Resenhas e opiniões \\
Dicas de produtos \\
Tutoriais \\
Novidades \\
Informações mais detalhadas \\
Produtos similares \\
\hline
\end{tabular}

Fonte: Autora

\subsection{Motivações para acessarem os blogs}

Vários autores mencionam algumas das principais motivações para que os indivíduos acessem blogs. Por meio das entrevistas realizadas, verificou-se que algumas das respostas dadas pelas entrevistadas, são similares às motivações descritas na literatura, sobretudo no que diz respeito ao entretenimento e à pesquisa de informação, tal como propõe Kulmala (2011).

Mediante os dados obtidos conseguiu-se perceber que uma das principais motivações das seguidoras deste tipo de blogs é a obtenção de informação acessível. "Acesso pela informação que está disponível de maneira mais fácil e acessível" (Camila), ou a procura de uma forma de distração e entretimento "Além de procurar informações e dicas, eu acesso como forma de distração também" (Manoela), e "Não consulto ou acompanho um blog só quando eu vou comprar, as vezes é pela experiência. Gosto de ver as opiniões sobre os produtos, ler um pouco sobre a vida da blogueira, a parte de viagens. É uma forma de distração que eu curto" (Patricia).

Algumas das entrevistadas relataram ainda outras motivações como a busca por inspirações "Inspirações de looks e maquiagens" (Bianca), o desejo de 
se manter informada "... geralmente leio mais para me reciclar mesmo. Me manter informada, ver as tendências, novidades" (Karina).

Adicionalmente, as entrevistadas foram questionadas se costumam acompanhar as novidades do mercado por meio dos blogs. A maior parte das entrevistadas responderam que têm mais o hábito de pesquisar acerca de um produto ou marca específica para saber mais detalhes e informações acerca do mesmo, e assim, às vezes, acabam conhecendo uma nova marca ou produto, "Não muito. Já conheci sem querer, mas foi enquanto eu estava pesquisando acerca de um produto específico, aí vi outras opções" (Larissa), "Não tenho costume de acessar blogs para saber novidades de mercado, mas já conheci produtos por meio desses, MARY KAY, por exemplo. Costumo acessar para pesquisar determinado produto antes de comprar" (Miria).

Para algumas entrevistadas, além de ajudar a obter mais informações sobre uma marca ou produto, a pesquisa também contribui na avaliação das alternativas existentes no mercado, assim, aumentando as opções de escolha, "Quando eu acesso é para saber mais sobre algum produto ou marca que já tenho em mente. Mas já pesquisei tipo "protetor cabelo sol" para saber quais são as opções no mercado, quais são melhores" (Débora), "Costumo ser objetiva nas minhas procuras pelos blogs, geralmente já tenho a ideia de um produto que alguém me falou sobre, porém, dentro dessas pesquisas sempre encontro algum produto semelhante ao que eu estou procurando e isso aumenta a minha opção na escolha da compra" (Rafaela). Percebe-se, tal como defende a literatura, que por meio da avaliação das alternativas o consumidor pode obter as informações necessárias e avaliar os benefícios que o produto pode trazer a ele (ENGEL, BLACKWELL, MINIARD, 2000).

Em contrapartida, algumas entrevistadas afirmaram que têm costume de acessar os blogs a fim de acompanhar as tendência e novidades mesmo sem intenção de compra, "Sim, gosto de saber das novidades do mercado através de blogs e já conheci alguns produtos desta forma. Não acesso para saber de marcas específicas, somente quando já tenho intenção de comprar. As novidades eu acompanho diariamente" (Camilla), "Sim, muitas vezes procurei alguns outros blogs só para poder ver matérias maiores sobre alguns produtos que não conhecia muito ainda ou que vi em algum anuncio, ouvi alguém falar rapidamente" (Karina).

Rebeca e Denise responderam que antes possuíam o hábito de acompanhar as tendências, mas atualmente não têm mais esse costume ou por falta de paciência. "Antigamente seguia os blogs para acompanhar as 
tendências, hoje em dia não tenho mais essa paciência e dedicação. Mas já conheci e comprei vários produtos por causa dos blogs" (Rebeca), ou pelo excesso de estímulo ao consumo, "Já fiz muito isso. Não faço mais, pois isso estimula o consumismo desenfreado. Atualmente, quando preciso de algum produto pergunto para minhas dermatologista, cabelereira e esteticista e depois pesquiso em blogs" (Denise).

\subsubsection{Boca-a-boca}

O presente trabalho também procurou entender se após a leitura de publicações de blogueiras, as consumidoras tendem a realizar boca-a-boca das informações obtidas. O que se encontrou foi que todas as entrevistadas compartilham com outras amigas as informações encontradas em blogs. 0 Quadro 6 resume o que as entrevistadas costumam compartilhar com as suas amigas.

Quadro 6: Informações compartilhadas pelas entrevistadas

\begin{tabular}{|l|}
\hline Informações compartilhadas \\
Produtos interessantes \\
Novidades \\
Matérias interessantes \\
Resenhas \\
\hline
\end{tabular}

Fonte: Autora

O boca-a-boca, geralmente, ocorre quando as entrevistadas viram ou usaram algum produto que gostaram, ou leram alguma matéria ou resenha interessante em algum blog, "...se vejo algum produto muito interessante e que sei que alguma amiga minha vai curtir" (Giulia). "Costumo também indicar para amigas resenhar que li e gostei" (Rebeca). Ou seja, as próprias consumidoras também passam a ser difusoras de conhecimento e opinião, e, por sua vez, acabam divulgando o produto/marca/blogs e amplificando 0 alcance das informações obtidas. 


\subsubsection{0 aumento do interesse pelos temas de moda, estilo e beleza}

Conforme foi verificado ao longo das entrevistas realizadas, o fato das entrevistadas acessarem blogs relacionados a moda, estilo e beleza, com certa frequência ocasiona o aumento do interesse nos temas abordados. Ao serem questionadas se o seu interesse pelos temas havia aumentado devido aos blogs, a maioria das entrevistadas respondeu que sim, conforme ilustra o Quadro 8.

No decorrer das entrevistas foram apontados motivos variados para esse aumento de interesse. Abaixo estão algumas das respostas obtidas:

Sim, acho que fiquei com um pouco mais de vontade de comprar as coisas. Isso te incita um pouco. E eu vi que eu precisava me cuidar mais também, eu poderia estar fazendo isso e aquilo para melhorar minha aparência e cabelo. $E$ mulher é um bicho vaidoso, eu sinto que isso só aflorou essa coisa mais na mulher. (Camila)

Aumenta a vontade de querer me cuidar mais, e com os anos passando a preocupação em ter uma pele bem cuidada aumenta também. Só não compro mais porque as coisas estão muito caras. (Raquel)

Sim, acho que por ver boas referências. Quando a gente aprende mais sobre moda acaba aprendendo a se valorizar mais, e a criar um estilo próprio. A vontade e a motivação para se cuidar aumenta também. (Karina)

Tem sim. Acho que por ter um maior acesso a esse mundo, os horizontes se ampliaram e, consequentemente, o interesse também. (Camilla)

Acho que isso é natural. Quanto mais você acessa, mais produtos você conhece, tem mais opções de compra. Você vê a variedade de produtos que existem e acaba estimulando esse lado consumista e vaidoso. (Débora)

Sim, como já falei, meu interesse e conhecimento sobre beleza e estilo cresceu em $90 \%$ com os blogs, aprendi como se maquiar, quais são as melhores as marcas, quais produtos ficam melhores na minha pele ou cabelo, conheci quase todos os produtos que tenho vi em blogs, e até onde comprar mais barato (como o Strawberrynet.com que conheci no Fashionismo) (...) A partir do Fashionismo fui conhecendo outros e é incrível como eu aprendi sobre beleza, estilo, cuidados com a pele com eles. Antes eu não tinha o mínimo interesse sobre isso. (Giulia)

Sim, um interesse está aumentando muito. Eu acho que é uma forma de incentivar os jovens, buscar uma referência, um site de uma pessoa que fale sobre aquilo que você gosta, sobre o que tem interesse. (Patricia) 
Mediante esses depoimentos, foi possível notar que algumas das entrevistadas mencionaram que os blogs contribuíram para o aumento na vontade e motivação para se cuidarem mais. Outro ponto a ser destacado é o conhecimento adquirido nos blogs que, por sua vez, também acaba aumentando mais ainda o interesse pelos temas. Foi mencionado também o fato dos blogs serem vistos como uma referência para algumas jovens.

Apenas quatro entrevistadas responderam que o seu interesse não aumentou, sendo que Denise admitiu já ter sofrido maior influência no passado "Antes sim, bastante. Atualmente, não mais. Pois percebi que isso estava estimulando meu consumismo. Resolvi dar uma freada nisso", e Manoela afirmou que o interesse se manteve igual "... continua o mesmo. Sempre gostei dessas coisas, de ler sobre dicas de beleza, sempre fui muito vaidosa".

\subsubsection{Influência das autoras de blogs de moda, estilo e beleza}

$\mathrm{Na}$ visão de Kulmala (2011), líderes de opinião estão estreitamente relacionados ao boca-a-boca eletrônico e proporcionam uma melhor imagem do processo de comunicação. Líderes de opinião influenciam os consumidores com seu estilo e comentários sobre tendências. Andreassen e Streukens (2009, apud Kulmala, 2011, p. 18) defendem que leitores de blogs estão mais abertos a processar informação proveniente do eWOM, pois eles mesmos buscam a informação. Para Rogers (2003, apud Halvorsen et al., 2013, p. 2014), canais de comunicação de massa alcançam mais pessoas, mas canais interpessoais, como blogs, são muito mais efetivos em mudar atitudes e influenciar a decisão de aprovar ou rejeitar um novo produto

Neste tópico, procurou-se compreender a influência que as autoras dos blogs podem exercer sobre as consumidoras e a imagem que as leitoras têm das blogueiras.

Os depoimentos estão de acordo com a suposição de Solomon et al. (2006) de que os blogs são uma importante fonte de influência e inspiração na busca e consumo de produtos por parte dos consumidores. O uso de blogs e sites como fonte de inspiração, também foi realçado no estudo de beleza da Popsugar Insights (2014). A pesquisa verificou que, no que diz respeito ao conteúdo digital considerado mais inspirador, mais da metade das entrevistadas consideram os sites e blogs de beleza como a maior fonte de inspiração.

De acordo com as respostas obtidas percebeu-se que as blogueiras de fato são vistas como pessoas criativas e dinâmicas que servem como fonte de 
inspiração e influência para as consumidoras. Para as entrevistadas é importante também que haja uma identificação com a blogueira em questão, como relatou Giulia "Uma blogueira é alguém que eu levo em consideração as opiniões e me identifico". Cada vez mais as blogueiras de moda, estilo e beleza criam empatia com as suas leitoras e as influenciam mais nas suas decisões de compra. Engel, Blackwell e Miniard (2000) concluem que a fonte e o receptor são similares em termos de características demográficas e estilos de vida, e caracterizam os líderes de opinião como pessoas ativas socialmente, conscientes de moda e independentes.

De acordo com Belch e Belch (2011, apud Halvorsen et al., 2013, p. 2015), a influência das blogueiras sobre as leitoras deve-se ao fato de serem consideradas ícones da moda, enquanto ao mesmo tempo os leitores mostram um engajamento pessoal na vida da blogueira e podem considerá-las amigas. 0 depoimento de Patricia retrata a importância de se identificar com a blogueira e seu estilo de vida, bem como o engajamento na vida da blogueira "Todas as blogueiras que eu acompanho são batalhadoras. Elas começaram de baixo. A Bruna Vieira morava em Leopoldina, uma menina que começou o blog porque ela levou um fora na balada e ela começou a escrever porque não aceitava muito o corpo dela. Criou o blog para superar isso e ela viu que tinha meninas passando pelo mesmo problema que ela. E hoje em dia ela é blogueira, youtuber, colunista da Capricho, viaja, ganha press kit de várias marcas famosas, então aquilo me inspirou muito a lutar pelos meus sonhos. É uma fonte de inspiração, me identifico muito com ela". O Quadro 7 reúne algumas das respostas dadas pelas entrevistadas quando questionadas sobre o que é ser uma blogueira.

Quadro 7: Descrição das blogueiras segundo as entrevistadas

\begin{tabular}{|l|}
\hline Uma blogueira é... \\
\hline Uma pessoa criativa e dinâmica \\
\hline Uma influenciadora que deve ter carisma, profissionalismo e visão para tendências \\
\hline Uma fonte de inspiração \\
\hline Uma pessoa empreendedora \\
\hline Verdadeira \\
\hline Alguém em quem confio e me identifico \\
\hline Uma pessoa antenada \\
\hline
\end{tabular}


Uma comunicadora que tem a responsabilidade de falar a verdade

Uma pessoa inteligente, estilosa e confiante

Fonte: Autora

No decorrer das entrevistas houve um relato interessante por parte da Denise: "Devem ser verdadeiras e não só fazer publicidade. Pois no início, os blogs eram mais verdadeiros e agora se vê muitas blogueiras se "vendendo" por publicidade". Esta resposta aponta a polémica provocada pelos incentivos que as marcas dão às blogueiras para que produzam conteúdo sobre os seus produtos. Segundo Noppari (apud Kulmala, 2011, p. 9), as blogueiras devem ser transparentes e mencionar quando o conteúdo publicado é patrocinado por alguma marca. Miria também destacou a importância da honestidade das blogueiras: "A blogueira é uma comunicadora que detém a responsabilidade de falar a verdade sobre o que testam e o que escrevem, diversas pessoas de muitas classes sociais leem ou assistem diariamente informações que estão acessíveis na internet e a responsabilidade do que falam ou escrevem é de suma importância".

Quando questionadas se haviam sido influenciadas por conteúdos publicados pelas blogueiras, a maioria a respondeu que já compraram um produto ou deixaram de comprar ao ler um blog. Apenas duas entrevistadas responderam que não. Algumas entrevistadas deram exemplos retratando esse tipo de situação:

Normalmente tudo o que compro eu vejo em blogs. Mesmo se eu decidir comprar sem ter visto no blog, eu entro no blog para saber a opinião das blogueiras sobre o produto em questão. Itens de maquiagem principalmente (Camilla).

Eu já comprei por indicação. Recentemente eu vi um vídeo da Bruna onde ela ganhou o perfume Chocolate da Boticário que eu acabei comprar de presente para minha mãe para o Dia das Mães. Me influenciou muito, mas nunca deixei de comprar um produto que é meu xodó por causa de alguma indicação (Patricia).

Comprei produtos que vi em publicações e tinham uma avaliação positiva. Só não deixo de comprar um produto que já seja meu preferido (Denise).

Deixei de comprar um produto que a minha dermatologista tinha passado. Era uma base com protetor solar, fiquei receosa e decidi pesquisar bastante e acabei não comprando (Larissa).

Já me influenciaram sim. Especialmente em relação a produtos para o rosto que são produtos que acho importante pesquisar bem a respeito antes de comprar ou não. Mas não deixo de 
comprar produtos que já sei que ficam bem em mim e são bons para a minha pele (Manoela).

E da mesma forma que as blogueiras podem influenciar as consumidoras a efetuarem uma compra, podem também influenciá-las a não comprarem por terem avaliado o produto negativamente, como relatou Débora: "Já tive produtos em mente que eu não tinha experimentado ainda, e fui ver a opinião nos blogs para ver se valia a pena e acabei desanimando de comprar", bem como Larissa: "Já deixei de comprar alguns produtos, fiquei receosa e decidi pesquisar bastante e acabei não comprando. Já troquei também um sabonete de rosto que eu usava por outro devido a alguma recomendação vista em blogs". Kulmala (2011) defende que quando o eWOM é negativo, o impacto nos consumidores é maior do quando é positivo.

Entretanto, há consumidoras que não se restringem apenas à informação dada pela blogueira e fazem as suas próprias avaliações sobre o produto, como relatou Karina: "Já fiquei sabendo de novos produtos, mas no geral eu não compro sem experimentar antes. Gosto de ir à loja física antes de comprar para testar a cor, consistência, etc. Por mais que a opinião delas seja importante, se eu discordar da avaliação, eu compro mesmo assim. Já Giulia destaca a importância de procurar opiniões de diferentes blogueiras: “... procuro não me basear em apenas uma blogueira, procurando diferentes opiniões sempre".

É também interessante observar que algumas entrevistadas destacaram o fato de não deixarem de comprar produtos que já usam há um tempo e gostam do resultado proporcionado devido a avaliação de alguma blogueira. Raquel destacou a importância da indicação vindo de uma especialista, como a sua dermatologista, quando o produto é específico para pele “... eu não deixo de comprar algum produto que a minha dermatologista indicou por conta da blogueira. Por conhecimento da análise da minha pele que não é a mesma pele da blogueira. Mas a maquiagem eu vou mais pela indicação de blog, de Instagram". Esse tipo de influência é informativa e ocorre quando o consumidor busca conselhos de pessoas que têm maior conhecimento a respeito das características do produto que deseja adquirir (SOLOMON, 2011).

A próxima pergunta tratava da receptividade das entrevistadas diante da apresentação dos produtos utilizados pelas blogueiras. Os depoimentos indicam um grande nível de influência pois todas as entrevistadas disseram que já sentiram vontade de usar um produto utilizado por uma blogueira e que já conheceram ou passaram a comprar uma marca apresentada por um blogueira. Abaixo estão alguns dos depoimentos obtidos por meio das entrevistas: 
Você vê a mulher toda bonita, e o jeito que elas falam, você fica um pouco tentada a experimentar as coisas (Camila).

Sim, algumas vezes. É normal. Você vê aquela mulher linda, com pele bem cuidada ou uma maquiagem perfeita. Acaba instigando um pouco sim (Manoela).

Principalmente os produtos para o cabelo. Tem um produto que eu conheci pesquisando em blogs, e amei. Uso sempre, é o Acquaflora, um protetor para o cabelo. Outra marca que conheci é a Orofluido (Débora).

Em relação à credibilidade das blogueiras, sob o ponto de vista de Engel (1995, apud Halvorsen et al., 2013 p. 214), transmissores de informação que são vistos como uma fonte confiável têm maior influência nos receptores. A influência a nível mais pessoal, geralmente, tem um impacto maior sobre o comportamento do que a nível comercial. Assim, as pessoas buscam informação de transmissores que são considerados confiáveis.

Quando questionadas se confiam na indicação de marcas ou produtos pelas blogueiras, a maioria respondeu que sim, porém, ressaltaram que confiam nas blogueiras que conhecem há um tempo, como relatou Camila: "Se eu conhecer a blogueira e o blog há um tempo, e já ter tido uma boa experiência ao usar algum produto visto no site ", e Patricia: "Confio na indicação sim, pelo menos confio na indicação das blogueiras que sigo e conheço há um tempo". Algumas entrevistadas também destacaram a preocupação com as publicidades pagas, bem como a importância da leitora se identificar com a blogueira, como pode ser observado nos depoimentos abaixo:

Como eu falei, com o boom dos blogs, teve aumento de interesse por parte das empresas que fornecem amostras, pagam por posts. Isso faz com que eu fiquei um pouco com o pé atrás. Confio em algumas poucas que já conheço há um tempinho (Denise).

Depende. Nem sempre. Tem muitas publicações patrocinadas então é importante ficar de olho nisso. Sempre rento pesquisar mais opiniões seja de outras blogueiras ou com amigas mesmo (Manoela).

Sim, mas levo mais em consideração se for uma dica porque comprou e gostou, e não quando vejo que o post é patrocinado (Giulia).

Depende da blogueira. Tem que ser alguém que me passe confiança, que eu tenha uma certa identificação de estilo e gosto. E que seja verdadeira em relação aos posts pagos (Débora)

Depende da blogueira. Eu confiando na blogueira, confio na indicação dela. Eu vejo pela qualidade da pele, do cabelo. $O$ 
estilo de vida dela, que não seja uma coisa muito chamativa. Eu prefiro as que têm um estilo de vida mais saudável, mais discreto. Procuro as que eu me identifico mais (Raquel).

Quando questionadas se têm a intenção de continuar a recorrer aos blogs relacionados a moda, estilo e beleza para tomar algumas decisões de compra de produtos de beleza, todas as entrevistadas responderam que sim, como se pode verificar em alguns dos depoimentos:

Sim, pretendo continuar acessando. Principalmente como uma fonte de informação (Camilla).

Tenho, é uma ótima ferramenta de pesquisa (Débora).

Sim, tenho a intenção sim. Gosto de me cuidar e de saber das tendências (Manoela).

Por fim, a última questão procurou compreender a perspectiva das entrevistadas acerca da influência que os blogs de moda, estilo e beleza podem exercer sobre comportamento de compra das mulheres que os acessam.

Grande parte das entrevistadas considera que os blogs de moda, estilo e beleza mudaram o comportamento de compra das mulheres que os acessam porque Ihes permitiu ter maior acesso à informação, além de se sentirem mais motivadas a cuidar de si mesmas. O fato de estarem mais atentas às informações dos produtos, às tendências, opiniões e avaliações das blogueiras faz com que se tornem consumidoras mais atentas, avaliando diversos aspectos antes de comprar um produto. Entretanto, várias entrevistaram mencionaram também as influências negativas que podem ter sobre as consumidoras. Os depoimentos a seguir comprovam isso:

É legal, a gente tem tanta questão na nossa cabeça. Que quando a gente se sente bonita, você se sente bem. Boa parte do trabalho delas está nisso né. Ao mesmo tempo que ficamos mais consumistas - o que tem que ter um limite -, você fica mais confiante (Camila).

Acredito que influenciou de forma tanto de positiva e quanto negativa. Nós, consumidoras, com os blogs, temos mais acesso a informação (o que é bom já que eu não sabia nem passar lápis no olhos há 6 anos atrás e hoje saio como a Kim Kardashian para festas), porém ficamos mais suscetíveis a sermos influenciadas, e muitas blogueiras recebem dinheiro para anunciar produtos que não gostam ou não usariam, ou seja, fazem propaganda enganosa dos produtos, nos induzindo a comprar algo que elas não recomendariam de verdade. Então temos que ficar realmente atentas a isso, pesquisar a fundo sobre o produto, ouvir mais opiniões antes de se decidir por comprar algo (Giulia).

Acho que as mulheres passaram a se arriscar mais, diversificando os produtos que usam, além de aprender a usá- 
los corretamente. Fica difícil dizer até que ponto essa mudança é real, porque meu exemplo de mulher é a minha mãe que não usa quase maquiagem nenhuma. Mas o que eu vejo de mudanças em mim, eu poderia dizer que eu passei a comprar marcas melhores, e passei a ousar mais nas escolhas também (Karina).

Acho que mudou para positivo. Temos maior acesso à informação. Mais escolhas. Mas penso que às vezes passa um pouco dos limites e tudo que é em excesso é ruim. Temos que saber o limite entre o que é apenas desejo do consumismo e o que de fato precisamos (Manoela).

Acredito que sim. Ao mesmo tempo que nos ajuda ao disponibilizar informações de fácil acesso, e nos motiva a querer cuidar mais do nosso corpo, saúde, tem um lado meio negativo também. Esse lado do consumismo, e tem mulheres que ficam um pouco obcecadas com o corpo, defeitos, se sentem mal por não se acharem tão bonitas quanto algumas dessas blogueiras. Sem falar do lado monetário do negócio. Acho legal existir a oportunidade de se trabalhar com esse tipo de coisa, de moda e beleza, mas as vezes algumas blogueiras perdem a mão e perdem um pouco a autenticidade e acabam virando uma garota propaganda (Débora).

Eu acho que através do desejo. Às vezes você não está muito com vontade de comprar, mas você vê aquilo na sua frente, aí você para e pensa: "Poxa eu queria ter aquilo". E isso acaba te influenciando. Se você não tiver a capacidade de separar o que é desejo da necessidade, o marketing te influencia. Graças a Deus eu consigo separar o desejo da necessidade. Antes de eu querer alguma coisa eu vejo se meu bolso está disponível (Patricia).

Os blogs causaram uma mudança profunda no comportamento de compra das mulheres, porque antes dessa ferramenta de pesquisa e estudo o público ficava engessado aos rótulos, comerciais e poucas opiniões adquiridas sobre determinado produto, aumentando a chance de erro na compra, gasto de dinheiro desnecessário e frustração durante o uso (Rafaela).

Eu acho que na vida corrida é uma ótima ferramenta para você ter conhecimento de cuidados com a pele, e até distração mesmo, de incentivo, de motivação. Porque as blogueiras são mulheres muito femininas que te motivam a cuidar de si, do rosto, da pele, dos cabelos (Raquel).

Uma das conclusões do estudo "Beauty4U - As quatro dimensões da beleza feminina" (2015), realizado pela agência Grey Brasil, é que, com o maior acesso à informação, as mulheres pesquisam dezenas de opções para comprar. Isso as torna mais cautelosas e menos impulsivas na hora de efetuar a compra. Larissa também realçou o fato da maior disponibilidade de informação tornarem as consumidoras mais cautelosas: "Acredito que mudou bastante, acho que as pessoas compravam as coisas mais rapidamente. Agora as pessoas estão 
pesquisando muito antes de comprar. Tem um maior leque de opções e maior acesso a informação". 


\section{Conclusões e recomendações para novos estudos}

O objetivo do presente trabalho era compreender a influência que os blogs relacionados a moda, estilo e beleza têm no comportamento de compra das consumidoras de produtos de beleza. Para isso, foram realizadas entrevistas a consumidoras de produtos de beleza que acessem blogs pelo menos uma vez ao mês a fim de investigar a percepção das mulheres acerca do fenômeno dos blogs relacionados a moda, beleza e estilo e o impacto que os blogs relacionados a moda, estilo e beleza têm nas decisões de compra das mesmas.

As respondentes descobriram os blogs, principalmente, por meio de pesquisas sobre produtos realizadas na internet, por meio de amigas ou outras plataformas como as redes sociais. A maioria das entrevistadas os acessa diariamente ou mais de uma vez por semana. Observou-se que a frequência de acesso aumenta quando ocorre o reconhecimento da necessidade de comprar um produto. Segundo as entrevistadas, o acesso frequente contribui para o aumento do interesse nos temas abordados pelos blogs e também para o aumento na vontade e motivação para se cuidarem mais.

A possibilidade de obter um maior volume de informação, bem como a contribuição na avaliação das alternativas existentes no mercado e a busca por entretenimento são as principais motivações para ler blogs, similares às motivações descritas na literatura, principalmente no que diz respeito ao entretenimento e à pesquisa de informação, tal como propõe Kulmala (2011). Outras entrevistadas mencionam ainda outras motivações, como a busca por inspirações e o desejo de se manter informada em relação às tendências. Em geral, as respondentes afirmaram que consultam ou já consultaram algum blog antes de realizar um compra.

A busca de informações é uma importante etapa no processo de decisão e a sua principal motivação é o desejo de fazer melhores escolhas ao comprar um produto (Engel, Blackwell e Miniard, 2000). Segundo as entrevistadas, todas têm o hábito de buscar informações na fase pré-compra, sendo o ambiente online, seguido das opiniões de amigas os meios mais utilizados. A literatura destaca o papel importante que as ferramentas online, como blogs, assumem na pesquisa de informação por oferecerem aos consumidores um autêntico canal de 
comunicação (Rassega et al., 2015), além de lhes permite o acesso à uma grande quantidade e disponibilidade de informação (Wolfinbarger e Gilly, 2001)

De acordo com os depoimentos das entrevistadas as principais motivações para pesquisar informação são: acesso à informação mais detalhada, obter opiniões reais sobre os produtos, saber se o produto é adequado e ver explicações de como usá-lo. Assim, as respondentes não ficam limitadas às informações dadas pelas marcas nos rótulos ou propagandas e avaliam se 0 produto vale o investimento.

Os fatores sociais também têm uma grande influência no processo de decisão de compra dos consumidores. Em relação a opinião de terceiros, a maioria das entrevistadas afirmou ser importante nas suas decisões de compra de produtos de beleza. Os tipos de influências mencionados foram, principalmente, amigas, familiares, outros consumidores e especialistas, uma vez que tendem a confiar mais nessas pessoas.

Além de buscarem informação, as próprias consumidoras também passam a ser difusoras de conhecimento e opinião por meio da comunicação boca-aboca que, geralmente, ocorre quando as entrevistadas viram ou usaram algum produto que gostaram, ou leram alguma matéria ou resenha interessante em um blog.

Procurou-se entender também a influência que as autoras dos blogs podem exercer sobre as consumidoras de produtos de beleza e a imagem que as leitoras têm das blogueiras. No ponto de vista das entrevistadas os blogs são uma importante fonte de influência e inspiração na busca e consumo de produtos, e é importante também que haja uma identificação com a blogueira em questão. A influência das blogueiras sobre as leitoras deve-se ao fato de serem consideradas ícones da moda, enquanto ao mesmo tempo os leitores mostram um engajamento pessoal na vida da blogueira e podem considerá-las amigas (Belch e Belch apud Halvorsen et al., 2013, p. 2015). A maioria das respondentes já comprou ou deixou de comprar um produto devido a avaliações feitas por blogueiras. As entrevistadas também se mostraram receptivas diante da apresentação dos produtos utilizados pelas blogueiras e já sentiram vontade de usá-los.

Em relação à credibilidade das blogueiras, a maioria das respondentes ressaltou que confia nas blogueiras que conhecem há um tempo, e buscam informação de transmissores que são considerados confiáveis. 
Por último, buscou-se compreender a perspectiva das respondentes acerca da influência dos blogs relacionados a moda, estilo e beleza na mudança do comportamento de compra de produtos de beleza. De acordo com os dados obtidos, o maior acesso à informação e o aumento na motivação de cuidar de si mesmas são fatores que contribuíram para a mudança no comportamento de compra. As consumidoras estão mais atentas às informações e avaliações o que as torna mais cautelosas ao escolher um produto.

Assim, os resultados deste estudo apontam os blogs relacionados a moda, estilo e beleza como uma fonte de informação confiável que tem a capacidade de influenciar a decisão de compra das consumidoras de produtos de beleza. As blogueiras, por sua vez, conquistam cada vez mais o status de influenciadoras e líderes de opinião de moda, estilo e beleza, e os blogs são cada vez mais vistos como um poderoso canal de comunicação de produtos ou serviços.

Os resultados da pesquisa mostraram também que o crescente acesso aos blogs de moda, estilo e beleza e a influência que as blogueiras têm sobre as consumidoras, podem ter implicações gerenciais nas empresas de produtos de beleza. Como visto na análise dos resultados, os blogs são poderosas plataformas de comunicação e podem ser utilizados pelas empresas como ferramentas de divulgação de seus produtos. Os depoimentos mostraram que as entrevistadas tendem a confiar mais na informação proveniente da opinião e experiência de outros consumidores do que da informação disponibilizada pelas marcas e não gostam de ficar limitadas às informações dadas pelas marcas nos rótulos ou propagandas.

Assim, é interessante para as empresas avaliarem estratégias de marketing que envolvam os blogs e suas autoras, entretanto é preciso que a relação de parceria entre a blogueira e a empresas seja transparente visto que a publicidade velada é uma das maiores preocupações das consumidoras que acessam blogs de moda, beleza e estilo.

\subsection{Sugestões e recomendações para novos estudos}

O objetivo deste trabalho era compreender a influência que os blogs relacionados a moda, beleza e estilo têm no comportamento de compra das consumidoras de produtos de beleza.

A partir daqui futuros trabalhos podem se aprofundar no tema utilizando, por exemplo, perfis diferentes de consumidores e até adotar métodos quantitativos como complemento aos qualitativos. 
Seria também interessante realizar um estudo onde as blogueiras sejam o público alvo, visando compreender a percepção delas enquanto influenciadoras no processo de tomada de decisão das suas seguidoras.

Outro ângulo interessante para futuros estudos é analisar a importância e as implicações que o fenômeno dos blogs tem para as marcas, e o papel que essas plataformas online têm na comunicação e divulgação dos produtos, bem como o impacto nas consumidoras. 


\section{Referências Bibliográficas}

ALLSOP D. T, BASSET, B. R; HOSKINS, J. A. (2007). Word-of-Mouth Research: Principles and Applications. Journal of Advertising Research, v.47, n.4, 398411, 2007. Disponível em: < $<$ http://versatilesolutionsbb.com/web_documents/word_of_mouth_research_jar_d ec-07.pdf>. Acesso em: 14abr.2016.

AMARAL, I. Participação em rede: do utilizador ao "consumidor 2.0 " e ao "prosumer". Revista Comunicação e Sociedade, v. 22, p. 131 - 147, 2012. Disponível em: http://revistacomsoc.pt/index.php/comsoc/article/viewFile/1278/1220>. Acesso em: 14 abr.2015.

AMERICAN MARKETING ASSOCIATION. Definition of Marketing. 2013. Disponível em: <https://www.ama.org/AboutAMA/Pages/Definition-ofMarketing.aspx>. Acesso em: 18 set.2015.

ARAUJO, A. C. Os blogues e agenda-setting: influência da blogosfera portuguesa na agenda mediática. 2011. Dissertação (Mestrado em Informaçãp, Comunicação Novos Media) - Universidade de Coimbra, Coimbra, 2011.

ASSOCIAÇÃO BRASILEIRA DA INDÚSTRIA DE HIGIENE PESSOAL, PERFUMARIA E COSMÉTICOS. Panorama do setor. 2015. Disponível em: <https://www.abihpec.org.br/novo/wp-content/uploads/2015-PANORAMA-DOSETOR-PORTUGU\%C3\%8AS-11ago2015.pdf>. Acesso em: 10 abr.2016.

CHURCHILL, Gilbert A.; PETER, J. Paul. Marketing: criando valor para os clientes. 2.ed. São Paulo: Saraiva, 2003.

ENGEL, J. F.; BLACKWELL, R. D.; MINIARD, P. W. Comportamento do Consumidor. Tradução de Christina Ávila de Menezes. 8.ed. Rio de Janeiro: LTC, 2000.

ENGEL, J. F.; BLACKWELL, R. D.; MINIARD, P. W. Comportamento do Consumidor. São Paulo: Pioneira Thomson Learning, 2005.

GIL, Antonio Carlos. Como elaborar projetos de pesquisa. 4.ed. São Paulo: Atlas, 2002.

GREY. Beauty4U - As quatro dimensões da beleza feminina. 2015. Disponível em: <http://grey.com/brasil/news/key/beauty-4u_/id/11811/>. Acesso em: 10 abr.2016.

HALVORSEN, K.; J, COSTE-MANIÉRE, I.; STANKEVICIUTE, R. Can fashion blogs function as a marketing tool to influence consumer behavior? Evidence from Norway. Journal of Global Fashion Marketing, v.4, n.3, p.211-224, 2013. 
HAWKINS, D. I.; BEST, R. J.; CONEY, K. A. Consumer Behavior: building marketing strategy. 7.ed. Boston: Macgraw- Hill, 1998.

HENNIG-THURAU, T; GWINNER, K. P; WALSH, G; GREMLER, D. D. Electronic word-of-mouth via consumer-opinion platforms: what motivates consumers to articulate themselves on the Internet? Journal of Interactive Marketing, v.18, n.1, p.38-52., 2004. Disponível em: <http://www.marketingcenter.de//mm/research/publications/download/l11_Hennig -Thurau_el_al_JIM_2004_Electronic_WoM.pdf>.Acesso em: 14abr.2016

HERRING, S. C; SCHEIDT, L. A; BONUS, S; WRIGHT, E. Bridging the Gap: A Genre Analysis of Weblogs. Proceedings of the 37th Hawaii International Conference on System Sciences, p.1-11, 2004.

KOTLER, Philip. Marketing: edição compacta. São Paulo: Atlas, 1996.

KOTLER, P; ARMStRONG, G. Princípios de Marketing. 12.ed. São Paulo: Pearson Prentice Hall, 2008.

KOTLER, P; KELLER, K. Administração de Marketing. 14.ed. São Paulo: Pearson, 2012.

KULMALA, MARIANNE. Electronic word-of-mouth in consumer fashion blogs, 2011. Master's Thesis (Marketing) - University of Tampere: School Of Management, Finlândia, 2011. Disponível em: $<$ https://tampub.uta.fi/bitstream/handle/10024/82564/gradu05048.pdf?sequence= 1>. Acesso em: 22 maio.2016

LAFLOUFA, Jaqueline. Digital, Social e Mobile 2015 - um compilado de dados e tendências digitais. 2015. Disponível em: <http://www.b9.com.br/54482/social-media/digital-social-e-mobile-2015-umcompilado-de-dados-e-tendencias-digitais/>. Acesso em: 25 mar.2016.

MAÇOLA, L.; VALE, I. N.; CARMONA, E. V. Avaliação da autoestima de gestantes com uso da Escala de Autoestima de Rosenberg. Revista da Escola de Enfermagem da USP. São Paulo, v.44, n.3, p.570-577, set. 2010. Disponível em: $\quad<\mathrm{http}: / /$ www.scielo.br/scielo.php?script=sci_arttext\&pid=S008062342010000300004>. Acesso em: 10 abr.2016.

MECCA, A. M.; SMELSER, N. J.; VASCONCELLOS, J. The Social Importance Of Self-esteem. Berkeley: University of California Press, 1989. Disponível em: < http://publishing.collib.org/ucpressebooks/view?docld=ft6c6006v5;chunk.id=0;doc .view=print $>$. Acesso em: 10 abr.2016.

MIKALEF, P.; GIANNAKOS, M.; PATELI, A. Shopping and Word-of-Mouth Intentions on Social Media. Journal of Theoretical and Applied Electronic Commerce Research, v.8, n.1, p.17-34., 2013. Disponível em: <http://users.ionio.gr/ mgiannak/JTAER2013.pdf>. Acesso em: 14 abr.2016.

MINTEL. Brasileiros gastarão mais de $\mathbf{R} \$ 450$ trilhões em 2019, representando crescimento de 37 entre 2014 e 2019. Disponível em: $<$ http://brasil.mintel.com/imprensa/estilos-de-vida/brasileiros-gastarao-mais-de-r450-tri-em-2019-representando-crescimento-de-37-entre-2014-e-2019>. Acesso em: 10. abr.2016. 
MOON, B-J. Consumer adoption of the internet as an information search and product purchase channel: some research hypotheses'. Int. J. Internet Marketing and Advertising, v.1, n.1, p.104-118., 2004. Disponível em: < http://www.cob.calpoly.edu/ ijima/7.pdf>. Acesso em: 14 abr.2016

MOWEN, John. C. Consumer Behavior. 4.ed. Englewood Cliffs: PrenticeHall, 1995.

MOWEN, J. C.; MINOR, M. S. Comportamento do Consumidor. São Paulo: Pearson Prentice Hall, 2003.

NC INCITE. Buzz in the Blogosphere: Millions More Bloggers and Blog Readers. $2012 . \quad$ Disponível em:http://www.nielsen.com/us/en/insights/news/2012/buzz-in-the-blogospheremillions-more-bloggers-and-blog-readers.html. Acesso em: 14 abr.2016

NIELSEN. Número de pessoas com acesso à internet no Brasil supera 120 milhões. 2014. Disponível em: <http://www.nielsen.com/br/pt/pressroom/2014/Numero-de-pessoas-com-acesso-a-internet-no-Brasil-supera-120milhoes.html >. Acesso em: 25 mar.2016.

NIELSEN. Global faces and Networked Places. 2009. Disponível em: <http://www.nielsen.com/content/dam/corporate/us/en/newswire/uploads/2009/03 /nielsen_globalfaces_mar09.pdf>. Acesso em: 18 abr.2016.

POLLACH, I. Electronic word of mouth: A genre analysis of product reviews on consumer opinion web site. Proceedings of the 39th Hawaii International Conference on System Sciences, Institute of Electronic and Electronics Engineers (IEEE), 2006. Disponível em: <https://www.computer.org/csdl/proceedings/hicss/2006/2507/03/250730051c.pd p> Acesso em: 20 abr.2016.

MC LOUGHLIN, Rob. POPSUGAR INSIGHTS. Disponível em: <http://insights.popsugar.com>. Acesso em: 20 abr.2016.

RASSEGA, V; TROISI, O; TORRE, C; CUCINO, V; SANTORO, A; PRUDENTE, N. Social Networks and the Buying Behavior of the Consumer. Journal of Global Economics, v.3, n.4, p.1-6., 2015. Disponível em: http://www.esciencecentral.org/journals/social-networks-and-the-buying-behaviorof-the-consumer-2375-4389-1000163.pdf>. Acesso em: 22 maio.2016.

RICHARDSON, R. J. Pesquisa social: métodos e técnicas. 3.ed. São Paulo: Atlas, 1999.

RITZER, G.; JURGENSON, N. Production, Consumption, Prosumption, Journal of Consumer Culture, v.10, n.1, p.13-36., 2010. Disponível em: <https://repositorio-aberto.up.pt/bitstream/10216/70762/2/16711.pdf>. Acesso em: 14 abr.2016

SECRETARIA DE COMUNICAÇÃO SOCIAL DA PRESIDÊNCIA DA REPÚBLICA. Pesquisa Brasileira de Mídia 2015: Hábitos de consumo de mídia pela população brasileira. 2015. Disponível em: < http://www.secom.gov.br/atuacao/pesquisa/lista-de-pesquisas-quantitativas- 
e-qualitativas-de-contratos-atuais/pesquisa-brasileira-de-midia-pbm2015.pdf>. Acesso em: 25 mar.2016.

SOLOMON, M. R. O Comportamento do Consumidor: Comprando, possuindo e sendo. 9.ed. Porto Alegre: Bookman, 2011.

SOLOMON, M. R.; BAMOSSY, G.; ASKEGAARD, S., \& HOGG, M. Consumer behaviour, a European perspective. 3.ed. Harlow: Pearson Education, 2006.

SOPHIA MIND. Influência da internet nas decisões de compra femininas. 2010. Disponível em: <http://www.sophiamind.com/wpcontent/uploads/SophiaMind_Influencia_Internet.pdf>. Acesso em: 25 mar.2016.

SOPHIA MIND. Consumo de produtos de beleza. 2009. Disponível em: <http://www.sophiamind.com/wp-content/uploads/SophiaMind_Beleza_rev.pdf> Acesso em: 10. abr.2016.

"VAIDADE" é a $4^{\text {a }}$ maior economia do mundo. Associação Comercial, Industrial e de Serviços do Estado de Goiás, 2015. Disponível em: < http://acieg.com.br/vaidade-e-a-4a-maior-economia-do-mundo/ >. Acesso em: 10. abr.2016.

VIEIRA, M. M. F.; ZOUAIN, D. M. Pesquisa qualitativa em administração: teoria e prática. Rio de Janeiro: FGV, 2006.

WOLFINBARGER, M.; GILLY, M. Shopping online for freedom, control, and fun. California Management Review, California, v.43, n.2, p. 34-55, 2001. Disponível em:

http://j.pelet.free.fr/publications/comparaison_brick_\%26_mortar_ecommerce/Sh opping_online_for_freedom_control_and_fun_WOLFINBARGER.pdf $>$. Acesso: 14 abr.2016

ZAGO, Gabriel. Dos Blogs aos Microblogs: Aspectos históricos, formatos e características. VI Congresso Nacional de História da Mídia, 2008. 


\title{
Anexo 1
}

\section{Roteiro da Entrevista}

\author{
Bloco 1 - Perfil \\ - Nome \\ - Idade \\ - Onde reside \\ - Grau de instrução \\ - Profissão
}

Você usa algum produto de beleza, como maquiagem, produtos para pele, rosto, mãos, unhas, etc.? Quais são os produtos de beleza que compra com mais frequência? E quais são os que mais utiliza? Quando você usa esses produtos?

Você tem produtos que comprou, mas não usa? Se sim, acredita que esse tipo comportamento possa ser influenciado por conteúdos vistos em blogs?

\section{Bloco 2 - Processo de decisão de compra}

O que você leva em conta ao escolher um produto de beleza? Pode dar exemplos?

Quando pretende comprar um novo produto costuma pesquisar informação sobre o produto antes de comprar? Se sim, onde costuma pesquisar essa informação e qual o motivo.

Nas suas decisões de compra, a opinião de outras pessoas (família, amigos e outros consumidores) é importante? Porquê?

\section{Bloco 3 - Influência dos blogs de moda e beleza}

Você acessa ou já acessou algum blog relacionado a moda, estilo e beleza? Quais? O que achou deles? O que você gosta neles? O que não gosta? 
Como descobriu os blogs relacionados a moda, estilo e beleza? Com que frequência os acessa?

Você consulta ou já consultou algum desses blogs antes de realizar uma compra? Que tipo de informação você estava procurando?

O que você procura nestes blogs? Por que os acessa?

Costuma acessar os blogs para conhecer as novidades do mercado? Já conheceu algum produto/marca por meio de um blog? Costuma acessar os blogs para se informar sobre um produto ou marca?

Já compartilhou com outras pessoas alguma informação encontrada em um blog?

Você acha que seu interesse pelos temas de moda, estilo e beleza, tem aumentado por acessar esse tipo de blog? Por quê?

Uma blogueira de moda, estilo e beleza é...

Os conteúdos postados por blogueiras já influenciaram as suas decisões de compra? (Já comprou ou deixou de comprar algum produto de acordo com a opinião de uma blogueira ou conteúdo visto em algum blog? Já preferiu comprar um produto diferente ao habitual devido à recomendação/publicação de alguma blogueira? Pode dar exemplos?

Alguma vez sentiu vontade de usar algum dos produtos utilizados pelas blogueiras?

Você conheceu ou passou a comprar alguma marca apresentada por alguma blogueira? Pode dar exemplos?

Você confia na indicação de marcas e/ou produtos feita pelas blogueiras?

Você tem a intenção de continuar a recorrer aos blogs relacionados a moda, estilo e beleza para tomar algumas decisões de compra de produtos de beleza (maquiagem, cuidados pessoais e higiene pessoal)?

$\mathrm{Na}$ sua opinião, de que forma acha que o fenômeno dos blogs relacionados a moda, estilo e beleza mudou o comportamento de compra das mulheres que os acessam? 